\title{
Multiple Sclerosis and Cancer: The Ying-Yang Effect of Disease Modifying Therapies
}

\author{
Esther Melamed $^{1 *}$ and Michael William Lee ${ }^{2}$ \\ ${ }^{1}$ Department of Neurology, Dell Medical School, Austin, TX, United States, ${ }^{2}$ Department of Oncology, Department of Medical \\ Education, Dell Medical School, Austin, TX, United States
}

Over the past two decades, the field of multiple sclerosis (MS) has been transformed by the rapidly expanding arsenal of new disease modifying therapies (DMTs). Current DMTs for MS aim to modulate innate and adaptive immune responses toward a less inflammatory phenotype. Since the immune system is also critical for identifying and eliminating malignant cells, immunosuppression from DMTs may predictably increase the risk of cancer development in MS patients. Compared with healthy controls, patients with autoimmune conditions, such as MS, may already have a higher risk of developing certain malignancies and this risk may further be magnified by DMT treatments. For those patients who develop both MS and cancer, these comorbid presentations create a challenge for clinicians on how to therapeutically address management of cancer in the context of MS autoimmunity. As there are currently no accepted guidelines for managing MS patients with prior history of or newly developed malignancy, we undertook this review to evaluate the molecular mechanisms of current DMTs and their potential for instigating and treating cancer in patients living with MS.

Danish Multiple Scle

Melinda Magyari,

Danish Multiple Sclerosis Center

Vincent K. Tuohy,

Cleveland Clinic, United States

*Correspondence:

Esther Melamed

esther.melamed@austin.utexas.edu

Specialty section:

This article was submitted to

Multiple Sclerosis and

Neuroimmunology,

a section of the journal

Frontiers in Immunology

Received: 10 September 2019

Accepted: 02 December 2019

Published: 10 January 2020

Citation:

Melamed E and Lee MW (2020)

Multiple Sclerosis and Cancer: The

Ying-Yang Effect of Disease Modifying

Therapies. Front. Immunol. 10:2954.

doi: 10.3389/fimmu.2019.02954

Keywords: multiple sclerosis, disease modifying therapy, cancer, treatment of autoimmune disease, multiple sclerosis drug mechanism, cancer treatment, multiple sclerosis treatment

\section{INTRODUCTION}

Multiple Sclerosis (MS) is a chronic autoimmune demyelinating disease of the central nervous system (CNS) and the leading non-traumatic cause of neurological disability in young adults. At diagnosis, most patients are started on a DMT, an immunomodulating or immunosuppressive therapy, that will likely be continued for life. While the DMT therapies have offered substantial benefit for MS patients, they have also introduced the potential for causing cancer as an adverse effect. With 17 DMTs available for the treatment of MS (Figure 1), clinicians are faced with the critical decision of how to screen MS patients for potential risk of malignancy with currently available DMTs and how to manage DMTs in MS patients who either had prior history of cancer or newly develop cancer while on a DMT.

The immune system plays an important role in both MS and cancer. It is possible that activation of the immune system in MS results in protective effects against cancer by increasing immunosurveillance, while chronic inflammation and use of certain immunosuppressive therapies could result in loss of immune protection against cancer or activation of the immune system to become pro-tumoragenic (1). At the same time, many of the available MS DMTs had been used for years as cancer treatments prior to being re-purposed for MS, such as rituximab, 


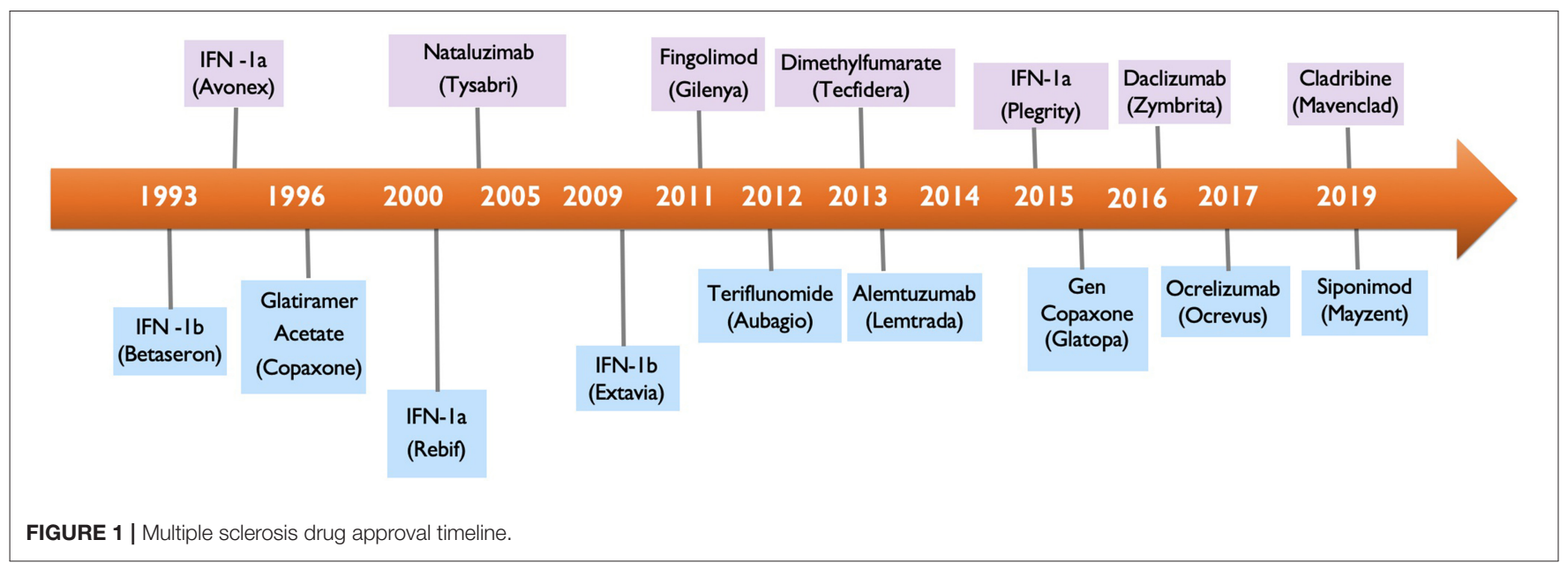

cladribine, and methotrexate, while other DMTs are actively being evaluated for their anti-tumor potential, such as dimethyl fumerate, fingolimod, and teroflunomide. This interesting dichotomy between the potential for cancer induction and cancer inhibition suggests that immunomodulatory and immunosuppressive MS medications may be acting in a context dependent manner in susceptible individuals.

The data on cancer prevalence and incidence in MS patients has been conflicting. Prior to the advent of oral and intravenous (IV) DMTs, studies suggested that the risk of cancer was equal $(2,3)$ or lower $(4-6)$ in untreated MS patients or in MS patients treated with interferons and Copaxone, while other studies suggested a higher risk of certain cancers. Incidence of breast cancers has been found to be increased $(2,3,7,8)$, decreased $(5)$, or the same $(9,10)$ in MS patients. Gastrointestinal cancers have been noted to be higher or lower in MS populations (1, 3). Urogenital (3, 11), central nervous system (8, 12), and skin cancers $(1,13)$ appear to be higher in the MS population. Several studies have found that while cancer risk in MS patients may not differ from the general population, the risk appears to be lower in male patients compared to female patients, and increases with age (7, 14, 15). Overall, there is general agreement that immunosuppressant therapies, such as azathioprine, methotrexate, cyclophosphamide, and mitoxantrone have led to increased cancer risks in MS patients and this risk is related to patient's family history of cancer, duration of treatment and cumulative dose $(16,17)$. More recent large cohort studies, have incorporated oral and IV therapies along with other cancer risk factors, such as alcohol and smoking, demonstrating no increase in cancer risk in MS population $(7,18,19)$. Varying study outcomes have been attributed to differences in study design, methodology, sex of participants, accountability for environmental cancer risk factors, and participant geographical location. In addition, lack of long-term safety registries overseen by a central body, have led to bias in reporting and assessment of how cancer risk compares to the risk for the general population across different countries.
Our goal in this review is to concisely summarize the molecular mechanism of available DMTs and their mechanistic relationship with potential for causing and treating cancer. We hope that this review will be of interest to clinicians caring for patients with MS, basic science immunologists, oncologists, and cancer biologists.

\section{FIRST APPROVED DISEASE MODIFYING THERAPIES IN MS}

\section{Interferon- $\beta$ Therapies: Betaseron, Avonex, Rebif, Plegridy}

Interferon- $\beta$ (IFN- $\beta$ ) therapies revolutionized management of MS as the first MS specific DMTs, following their initial approval in 1990's. Interferons differ in the frequency and mode of administration, for example betaseron, rebif, and plegridy are subcutaneous, while avonex is intramuscular. The pegylated IFN$\beta$-1a, plegridy, has a long half-life and is administered once every 2 weeks. IFN- $\beta-1 b$ is made and purified from Escherichia coli, and has amino acid differences from the body's own IFN$\beta$, while IFN- $\beta-1 \mathrm{a}$ is manufactured in the Chinese hamster ovary cell line and has the same protein sequence as the native IFN- $\beta$.

Interferons are cytokines that are naturally produced in the body in response to immune stimulation, viral infections, and other chemical stimulation (20). Isaacs, Lindenmann, Paucker, and others, defined interferons as antiviral agents with potential for antigrowth and anti-inflammatory activity. IFNs are now classified as Type I (IFN- $\alpha, \beta$, and $\omega$ ), Type II (IFN- $\gamma$ ) or Type III (IFN- $\lambda$ ). Although both IFN- $\alpha$ and IFN- $\beta$ have been studied in MS, IFN- $\beta$ therapies have been shown to be superior in the management of MS, likely due to their higher immunoregulatory actions and less severe adverse effects profile (21-23). It is noteworthy though that a preserved in vivo response to IFN- $\alpha$ has been observed in MS patients with neutralizing antibodies against interferon-beta and that IFN- $\alpha 2$ a reduces MRI disease activity in relapsing-remitting multiple sclerosis (RRMS) (22). IFN $\alpha$ has been shown to be an important antiviral therapy in the treatment of hepatitis B and C, HIV, herpes 
zoster, as well as in the management of different malignancies, including melanoma, chronic myelogenous leukemia (CML), B cell leukemia (BLL), follicular lymphoma, non-Hodgkin's lymphoma, mycosis fungoides, multiple myeloma, AIDS-related Kaposi's sarcoma, carcinoid, and also bladder, renal, epithelial ovarian, and skin cancer (24). IFN- $\beta$ - 1 a has also been used in the treatment of adrenocortical and carcinoid cancers $(25,26)$.

Mechanistically, type I interferons signal through interferon alpha/beta receptor-1 (IFNAR1) and interferon alpha/beta receptor-2 (IFNAR2), leading to activation of tyrosine kinase 2 (Tyk2) and janus kinase-1 (JAK1), signal transducer and activated transcription-1 (STAT1) and signal transducer and activated transcription-1 (STAT2) phosphorylation cascades, and ultimately activation of hundreds of genes important in IFN mediated immune and antiproliferative functions (27). In MS, IFN- $\beta$ is thought to down-regulate major histocompatibility complex II (MHC II) expression and decrease lymphocyte activation (28). IFN- $\beta$ mediated increases in apoptotic markers, Annexin- $\mathrm{V}$ and caspase-3, leads to specific B memory cell depletion. Additional mechanisms for IFN- $\beta$ include downregulation of adhesion molecules such as very late adhesion-4 (VLA-4), it's ligand vascular cell adhesion moleculae1 (VCAM-1), and matrix metalloproteinase (MMP), resulting in lower transmigration of lymphocytes across the bloodbrain barrier (23). Activation of STAT1/STAT2 also contributes to secretion of anti- inflammatory cytokines, e.g. Interleukin 10 (IL-10), which can shift the immune profile toward antiinflammatory T helper 2 (Th2) cells (29).

Both immune cells and tumor cells can produce interferons in a complex interplay. Type I interferons, such as IFN- $\alpha$ and IFN$\beta$, produced by plasmacytoid dendritic cells can lead to multiple, diverse, downstream actions (24). These include upregulation of MHC I on APCs and expression of tumor cell antigens $(30,31)$, differentiation of CD8+ T cells into cytolytic effector cells (32), downregulation of T regulatory cells (33), reduction in IL-12p40 (34), and upregulation of IL15 together with further lymphocyte expansion (30). Type 1 IFN-orchestrated actions contribute toward inhibition of tumor cell differentiation, proliferation, migration and an increase in tumor cell death. IFN- $\alpha$ and $-\beta$ can inhibit tumor cell growth in different malignancies in specific ways. For example, in neuroblastoma, IFN- $\beta$ can induce apoptosis via downregulation of phosphatidylinositol 3kinase/protein kinase B signaling (35). In melanoma and breast cancer, IFN- $\beta$ induces cell death via the extrinsic TNF-relatedapoptosis-inducing-ligand (TRAIL)-dependent pathway (36). In cervical cancer, Type I interferons signal via the extrinsic cellular FLICE (FADD-like IL-1 $\beta$-converting enzyme)-inhibitory protein (cFLIP) and caspase-8 ligands (37). Interestingly, tumor cells, by means of somatic copy number alterations (SCNA), can "turn off" IFN- $\alpha$ and IFN- $\beta$ production by homozygously deleting their respective genes (38). These mechanisms could potentially allow cancer cells to evade the immune system and metastasize.

There were no cancers associated with IFN- $\beta$ in MS clinical trials. However, since the initial Federal Drug Administration (FDA) approval of IFN- $\beta$, there has been a trend for breast cancer noted in a study of the British Columbia MS database, evaluating a cohort of 5146 relapsing-onset MS patients and
48,705 person-years of follow-up, that did not reach statistical significance (39).

\section{Glatiramer Acetate (Copaxone)}

Glatiramer acetate (GA), was approved in 1996 in the US and in 2001 in Europe for RRMS and became the second non-interferon DMT to be approved for MS. It is an amino acid polymer, originally developed as an agent to mimic myelin basic protein in an effort to induce autoimmune encephalomyelitis (EAE) in an MS mouse model (40). The result of administrating GA to mice was a paradoxical improvement in EAE, and these studies paved the way toward open-label MS trials in patients (41). GA is administered subcutaneously.

The mechanism of action of GA is not fully understood, and likely involves activation of both the innate and adaptive immune systems, upregulation of anti-inflammatory M2 monocytes, Th2 cells and T regulatory cells (Tregs) (42). Studies using radiolabeled GA demonstrate that the gastrointestinal tract and thyroid gland contain the highest GA levels, with lowest levels in the CNS. GA and its metabolites are hydrophilic, which might prevent its crossing the blood-brain barrier, pointing toward largely peripheral actions of GA in MS (43).

Despite relatively lower efficacy in disease modulation, GA is considered to have a strong safety profile and no cancers were reported in clinical trials. In the post-marketing era surveillance, one study found an increased relative risk for breast cancer for females, though this was not statistically significant (9). Other studies have not found a significant association between GA and breast cancer $(16,39)$. Several skin cancers have been reported in patients on GA, including one case study of primary cutaneous anaplastic large- cell lymphoma and one case study of melanoma $(44,45)$.

\section{LYMPHOCYTE TRAFFICKING INTERRUPTION: NATALIZUMAB AND SPHINGOSINE-1-PHOSPHATE RECEPTOR AGONISTS}

\section{Natalizumab (Tysabri)}

Natalizumab is the first monoclonal antibody for management of MS, approved in 2004, and remains one of the most potent DMTs in MS. By selectively blocking lymphocyte $\alpha 4 \beta 1$ integrin, natalizumab effectively prevents lymphocyte transmigration across the blood brain barrier to the CNS (46).

Natalizumab would appear to be a promising anti-cancer drug due to its ability to block cell adhesion. For example, $\alpha 4 \beta 1$ integrin is necessary for melanoma metastasis into lymph nodes and integrins are important for tumor angiogenesis (47). Although natalizumab has been considered as a treatment for multiple myeloma (48) and certain stages of melanoma (49), it has not overall proven to be a successful candidate in cancer therapeutics. Part of the reason is thought to relate to differences in leukocyte and cancer cell extravasation into tissues. Whereas, leukocytes heavily rely on integrins for migration into inflamed tissues, cancer cells have evolved complex and varied approaches to interact with their microenvironment for 
metastasis. Cancer cells either do not use integrins due to transition from mesenchymal to ameboid forms, can express multiple adhesive receptors, or can switch from the use of one integrin to another for adhesion and metastasis (50).

Several types of cancers have been reported with natalizumab use, including melanoma, breast cancer and diffuse large $\mathrm{B}$ cell lymphoma (Table 1) (52). The mechanism to explain susceptibility to natalizumab-associated cancers likely has to do with decreased $\mathrm{T}$ cell migration to tumor sites due to blocking of $\alpha 4$ integrin which interferes with antigen-specific $\mathrm{T}$ cells activation (78). Interestingly, $\alpha 4 \beta 1$ integrin may also play a role in reducing the invasive potential of melanoma cell lines (79).

The role of natalizumab in cancer is currently being evaluated in clinical trials in pulmonary metastatic osteosarcoma (NCT03811886), and has previously been evaluated in multiple myeloma (NCT00675428) and acute-graft-vs-host disease (NCT02133924, NCT02176031).

\section{Sphingosine 1-P Receptor (S1PR) Receptor Modulators: Fingolimod (Gilenya) and Siponimod (Mayzent)}

S1PR modulators play an important role in both MS and cancer. Fingolimod (FTY720, Gilenya) was the first oral therapy approved for MS in 2010. Siponimod is the most recent FDA approved DMT for RRMS and secondary progressive MS (SPMS) as of April 2019. S1P modulator's mechanism of action has been extensively evaluated in preclinical studies in mouse models of MS as well as in vitro and in vivo models of tumorigenesis and transplant.

Fingolimod was originally synthesized from a natural compound myriocin, from a family of parasitic fungi, Cordyceps sinclarii (80), and shown to have potent immunosuppressant activity exceeding that of cyclosporine A $(81,82)$. Prior to this discovery, in traditional Chinese medicine, powder from another fungal subfamily, Cordyceps sinensis, had been widely used for its energy and "eternal youth" qualities (83). Fingolimod was subsequently demonstrated to be a prodrug analog of sphingosine, becoming phosphorylated into fingolimod-P by sphingosine kinase $2(\mathrm{~S} 1 \mathrm{~K} 2)$, and interacting with S1P receptors on various cell types, outcompeting the native S1P. Although Fingolimod-P can bind with all S1PRs except S1P2, it has highest affinity for S1P4 (84). Following binding to S1PRs, fingolimod leads to internalization of the S1PR on T and B cells, preventing their egress from secondary lymphoid organs, such as mesenteric lymph nodes and Peyer's patches, and leading to peripheral lymphopenia (81). Similarly to fingolimod, siponimod binds to $\mathrm{S} 1 \mathrm{P} 1$ receptors, leading to a decrease in peripheral immune cell egress from lymph nodes. Via its action on the S1P5 receptors in the CNS, siponimod is also thought to potentially contribute toward a decrease in extent and progression of neurodegeneration (85).

In competing with $\mathrm{S} 1 \mathrm{P}, \mathrm{S} 1 \mathrm{P}$ modulators participate in an intricate cellular machinery of sphingolipids, major components of eukaryotic cell plasma membranes, which play an important role in cellular fate and cell signaling. Sphingolipids such as ceramide and sphingosine are important in apoptotic machinery of programmed cell death, while S1P is involved in cell proliferation, migration, angiogenesis, inflammatory responses, and lymphocyte trafficking. Dysregulation in sphingolipid metabolism allows cancer cells to escape cell death via increasing S1P signaling, altering expression of ceramide degrading enzymes, and upregulation of sphingosine kinases, such as sphingosine kinase 1 (SK1) (86). Hence, as a sphingosine analog, fingolimod has been studied in in vitro and in vivo for its potential anticancer effects. Indeed, fingolimod has been shown in preclinical studies to have anticancer activity in various cancer cell types, including bladder cancer (87), breast cancers (88-91), glioblastoma $(92,93)$, hepatocellular carcinoma (94-96), malignant mesothelioma (97), leukemia and lymphoma (98-104), lung cancer (105-107), liver cancer (108), pancreatic cancer (109), bladder cancer (87), renal cancer (110); glioma (111), gastrointestinal cancer (112), and ovarian cancer (113). Fingolimod has also been shown to be an important therapy sensitizer in several studies. For example, fingolimod demonstrates an additive effect with 5-fluorouracil, SN-38, and oxaliplatin (114), in colorectal cancer studies. It also leads to inhibition of tumor growth and induction of cancer cell apoptosis and mouse survival when used with cetuximab (115). Other anticancer effects of fingolimod include inhibition of metastasis in a mouse model of melanoma (116) and glioblastoma cell lines (93), and inhibition of microvessel formation in prostate tumor xenografts in mice (117). Fingolimod has strong immunosuppressive properties against Treg cells (118) that contribute to tolerance of malignant tumor cells (119) indicating fingolimod may have potential in post-transplant malignancies (120). Yet another potential anticancer mechanism of fingolimod is inhibition or degradation of SK1, which is upregulated in multiple cancers, including CNS (brain), gastrointestinal (colon, stomach, rectum, small intestine), genitourinary (ovary and uterus), pulmonary and breast (121). Overall, it is becoming clear that fingolimod has a multitude of anticancer effects in addition to its role in immunosuppression as an S1P modulator, that in part may be mediated via its unphosphorylated form (122).

However, despite fingolimod's significant potential as an anticancer drug, there are several caveats that preclude its sole use as a cancer treatment. First, given fingolimod's effect on lymphocyte sequestration, decreased $\mathrm{T}$ cell surveillance may enhance potential cancer development (Figure 2). Additionally, upregulation of B regulatory cells (Bregs) and IL-10 could serve as another mechanism of fueling potential tumorigenesis (123). To this degree, there are a low number of fingolimod associated malignancies that have emerged in clinical trials (Table 1) and in the post-clinical trial era, including melanoma, basal cell carcinoma, breast cancer, squamous cell carcinoma, large B cell lymphoma, ocular lymphoma, Merkel cell carcinoma, cutaneous CD30+ T-cell lymphoma and multiple myeloma. Additionally, doses required for fingolimod's antitumor effects far exceed the dosing currently approved for fingolimod in MS and may lead to unwarranted side effects (124). Still, given its important role in tumor sensitization, Fingolimod could potentially be used as a sensitizer for cancer treatment alongside other cancer treatment strategies.

Perhaps in the future, other analogs of S1PR that are currently in different phases of preclinical and clinical trials, such as 
TABLE 1 | Summary of disease modifying therapies, their mechanisms of action, incidence of cancer in clinical trials, and studies of DMTs in different cancer types.

\begin{tabular}{|c|c|c|c|c|c|}
\hline Agent & Mechanism of action & $\begin{array}{l}\text { Cancer incidence in MS patients in } \\
\text { clinical trials }\end{array}$ & References & Assessed in cancer types & References \\
\hline & & Type(s) & & Type(s) & \\
\hline Interferons & $\begin{array}{l}\text { Activates IFN receptor linked } \\
\text { JAK/STAT pathways leading to } \\
\text { alteration of transcription of } \\
\text { immune and antiproliferative } \\
\text { genes; reduces migration of } \\
\text { lymphocytes across the blood } \\
\text { brain barrier }\end{array}$ & None & & $\begin{array}{l}\text { Breast, glioma, nasopharyngeal } \\
\text { carcinoma, neuroblastoma, } \\
\text { adrenocortical, pancreatic, and } \\
\text { carcinoid cancers }\end{array}$ & $(24,51)$ \\
\hline $\begin{array}{l}\text { Glatiramer } \\
\text { acetate }\end{array}$ & $\begin{array}{l}\text { Amino acid polymer; activation of } \\
\text { innate; and adaptive immune } \\
\text { system; shift toward more } \\
\text { protective Th2 immunity }\end{array}$ & None & & & \\
\hline Fingolimod & $\begin{array}{l}\text { sphingosine } 1 \text { phosphate } \\
\text { receptor (S1PR) modulator }\end{array}$ & $\begin{array}{l}\text { FREEDOMS II: RRMS ( } N=728) \text { :basal } \\
\text { cell carcinoma }(N=16) \text {, squamous cell } \\
\text { carcinoma }(N=4) \text {, uterine leiomyoma ( } N \\
=1 \text { ), thyroid cancer }(N=1) \\
\text { TRANSFORMS: RRMS ( } N=857) \text { : basal } \\
\text { cell carcinoma }(N=5) \text {, melanoma in situ } \\
(N=3) \text {, breast cancer }(N=4) \text { RMS ( } N= \\
\text { 188): basal cell carcinoma }(N=1) \text {, } \\
\text { squamous cell carcinoma }(N=1) \text {, } \\
\text { malignant melanoma }(N=1) \\
\text { INFORMS: PPMS ( } N=336) \text { : basal cell } \\
\text { carcinoma }(N=14), \text { squamous cell } \\
\text { carcinoma }(N=6) \text {, malignant melanoma } \\
\text { ( } N=1) \text {, breast cancer }(N=1) \text {, } \\
\text { non-Hodgkin's lymphoma }(N=1) \text {, } \\
\text { malignant lung cancer }(N=1) \text {, ovarian } \\
\text { cancer }(N=1) \text {, prostate cancer }(N=1)\end{array}$ & $\begin{array}{l}(53) \\
(54,55) \\
(56)\end{array}$ & $\begin{array}{l}\text { Breast cancer, lung, gastric tumors, } \\
\text { and metastatic melanoma }\end{array}$ & $(57,58)$ \\
\hline Cladribine & $\begin{array}{l}\text { Nucleoside analog, inhibits DNA } \\
\text { synthesis and DNA chain } \\
\text { termination; cytotoxic particularly } \\
\text { for lymphocytes and monocytes }\end{array}$ & $\begin{array}{l}\text { CLARITY: RMS }(N=889) \text { : benign uterine } \\
\text { leiomyosarcoma benign uterine } \\
\text { leiomyosarcoma }(N=5) \text {, cervical } \\
\text { carcinoma in situ }(N=1) \text {, melanoma ( } N= \\
\text { 1), ovarian carcinoma }(N=1) \text {, pancreatic } \\
\text { carcinoma }(N=1) \text {, myelodysplastic } \\
\text { syndrome }(N=1)\end{array}$ & (63) & $\begin{array}{l}\text { hairy cell leukemia, chronic } \\
\text { myelogenous leukemias and } \\
\text { non-hodgkins lymphomas }\end{array}$ & (64) \\
\hline Alemtuzumab & $\begin{array}{l}\text { Monoclonal antibody against } \\
\text { CD52 on T and B cells; } \\
\text { Depletion of peripheral } \\
\text { lymphocytes via CDC and ADCC }\end{array}$ & $\begin{array}{l}\text { CARE MS I } 5 \text { year follow up: RRMS ( } N \\
=376 \text { year } 1 \text { and } 2 ; N=340-360 \text { year } \\
3-5) \text { : thyroid papillary carcinoma }(N=2) \text {, } \\
\text { breast cancer }(N=1) \text {, keratoacanthoma } \\
(N=1) \text {, non-small-cell lung cancer }(N= \\
\text { 1), micropapillary thyroid carcinoma }(N= \\
\text { 1) } \\
\text { CARE MS II } 5 \text { year follow up: RRMS ( } N \\
=434 \text { year } 2 \text { and } N=412 \text { year } 3) \text { : thyroid } \\
\text { papillary carcinoma }(N=2) \text {, basal cell } \\
\text { carcinoma }(N=1) \text {, melanoma }(N=1)\end{array}$ & $(65,66)$ & $\begin{array}{l}\text { T cell lymphomas, peripheral T cell } \\
\text { lymphoma-not otherwise specified, T } \\
\text { cell prolymphocytic leukemia, } \\
\text { cutaneous T cell lymphoma and adult } \\
\text { T cell lymphoma/leukemia; B cell } \\
\text { malignancies: B cell Non-Hodgkin } \\
\text { lymphoma and B cell chronic } \\
\text { lymphotytic leukemia }\end{array}$ & (67) \\
\hline
\end{tabular}


TABLE 1 | Continued

\begin{tabular}{|c|c|c|c|c|c|}
\hline Agent & Mechanism of action & $\begin{array}{l}\text { Cancer incidence in MS patients in } \\
\text { clinical trials }\end{array}$ & References & Assessed in cancer types & References \\
\hline & & Type(s) & & Type(s) & \\
\hline Rituximab & $\begin{array}{l}\text { Monoclonal antibody against } \\
\text { CD20 on immature and mature B } \\
\text { cells; depletion of CD20 positive } \\
\text { B cells via CDC and ADCC }\end{array}$ & $\begin{array}{l}\text { RRMS }(N=557), \text { SPMS }(N=198), \text { PPMS } \\
(N=67) \text { : Basalioma }(N=2), \text { Pyoderma } \\
\text { gangrenosum }(N=1)\end{array}$ & (68) & $\begin{array}{l}\text { B cell lymphomas, Non-Hodgkin } \\
\text { lymphoma, Burkitt lympoma, and B } \\
\text { cell lymphoblastic leukemias }\end{array}$ & (69) \\
\hline Ocrelizumab & $\begin{array}{l}\text { Monoclonal antibody against } \\
\text { CD20 on immature and mature B } \\
\text { cells; depletion of CD20 positive } \\
\text { B cells via CDC and ADCC }\end{array}$ & $\begin{array}{l}\text { OPERA } 1 \text { and Opera 2: RRMS ( } N= \\
\text { 825): renal cancer }(N=1) \text {, melanoma ( } N \\
=1) \text {, and breast cancer }(N=2) \text { in RRMS } \\
\text { patients; } \\
\text { ORATORIO: PPMS ( } N=486 \text { ) breast } \\
\text { cancer }(N=4) \text {, basal cell cardinoma ( } N= \\
\text { 3), large cell lymphoma }(N=1) \text {, } \\
\text { endometrial carcinoma }(N=1) \text {, metastatic } \\
\text { pancreatic carcinoma }(N=1) \text { malignant } \\
\text { fibrous histyocytoma }(N=1)\end{array}$ & $(70,71)$ & $\begin{array}{l}\text { Relapsed/refractory follicular } \\
\text { lymphoma }\end{array}$ & $(72)$ \\
\hline $\begin{array}{l}\text { Dimethyl } \\
\text { Fumerate }\end{array}$ & $\begin{array}{l}\text { Modulates Nif2 and glutathione } \\
\text { levels in T cells; activates } \\
\text { antioxidant genes }\end{array}$ & $\begin{array}{l}\text { DEFINE: RMS }(N=826) \text { basal cell } \\
\text { carcinoma }(N=1) \text {, breast cancer }(N=1) \text {, } \\
\text { cervical cancer }(N=1) \text {, transitional cell } \\
\text { carcinoma }(N=1) \\
\text { CONFIRM: No neoplasms reported in } \\
\text { BG-12 (DMF) treated group }\end{array}$ & $(73,74)$ & $\begin{array}{l}\text { Lung adenocarcinoma, colon } \\
\text { adenocarcinoma, melanoma }\end{array}$ & $(75-77)$ \\
\hline
\end{tabular}

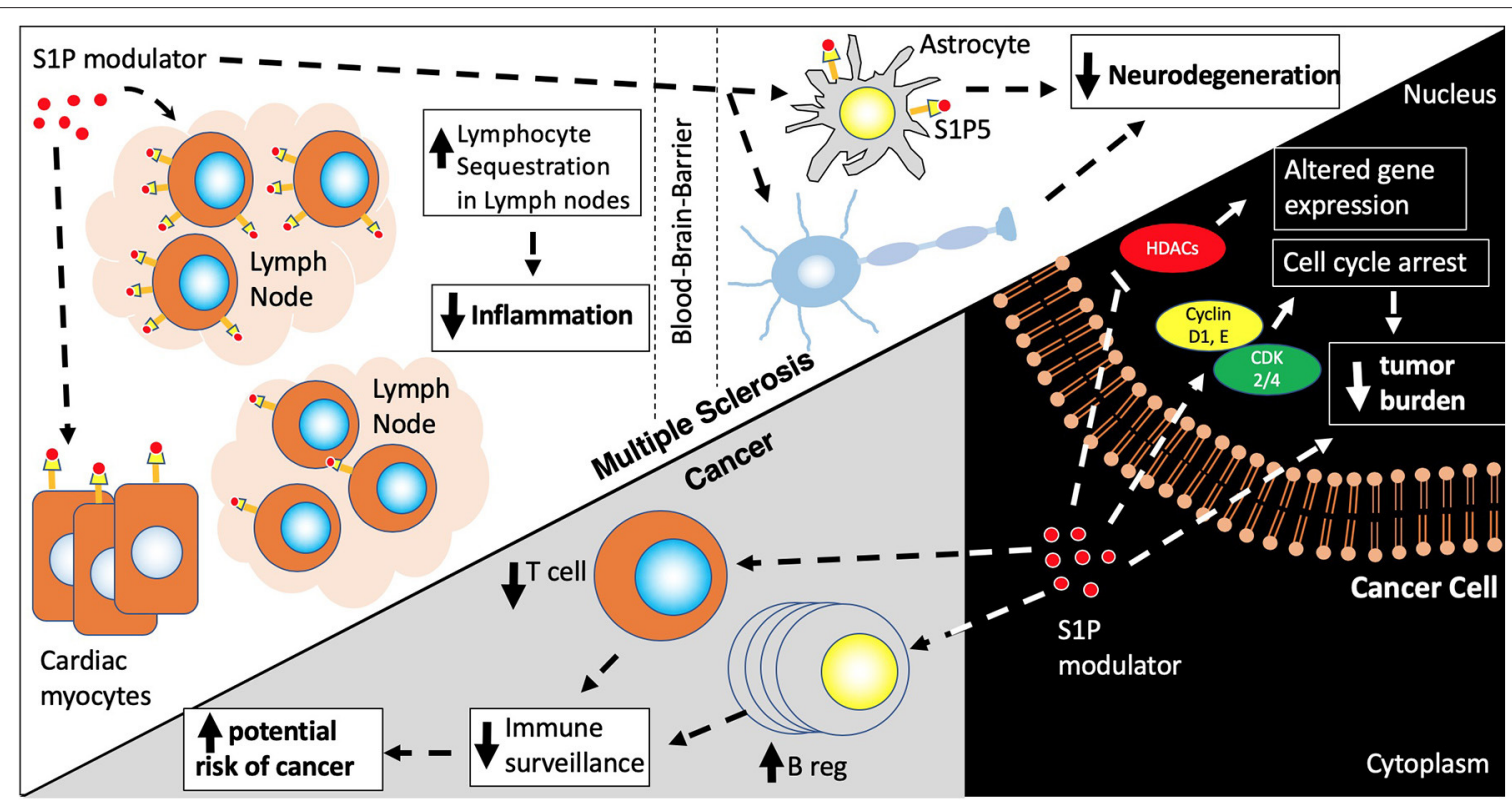

FIGURE 2 | S1P modulators. S1P modulators, Fingolimod and Siponimod, decrease egress of naïve memory, Th17, CD4/CD8 T cells, and plasma B cells from lymph nodes leading to a decreased inflammatory response and decrease in neurodegeneration via actions on the S1P receptors in lymph nodes, astrocytes and oligodendrocytes. S1P modulators also have actions on other cell types including cardiac myocytes contributing to first dose bradycardia. In cancer cells, S1P modulators activate pathways involved in cell cycle arrest and cell death via actions on histone deacetylases (HDACs) and cyclin/CDK cell cycle proteins. However, due to their effects on Bregs (increased) and T regs (decreased) there is a risk of increasing cancer incidence due to decreased immune surveillance.

SKI-178 (125), vs. liposomal formulations for targeted delivery of fingolimod will maximize anti-cancer effects and minimize immunosuppressive and other side effects of fingolimod. In addition, fingolimod could be used as a sensitizer at a relevant dose in patients with MS who may be diagnosed with other cancers. These considerations may guide clinician decision not to discontinue therapy but to use it as an adjuvant to other cancer treatments. 
A recent clinical trial has completed enrolling patients to evaluate fingolimod's role as a tumor sensitizer in patients with glioblastoma (NCT02490930).

\section{DNA SYNTHESIS INHIBITORS: TERIFLUNOMIDE (AUBAGIO) AND CLADRIBINE (MAVENCLAD)}

\section{Teriflunomide (Aubagio)}

Teriflunomide was the second oral drug to be approved for MS in 2012. Teriflunomide is an active metabolite of lefluonomide and acts via reversible inhibition of the mitochondrial enzyme dihydroorotate dehydrogenase (DHODH) necessary for de novo synthesis of pyrimidines. By halting DNA and RNA synthesis, teriflunomide affects actively dividing cells, such as $\mathrm{T}$ and $\mathrm{B}$ cells. Teriflunomide was associated with rare cases of cervical carcinoma in situ and uterine leiomyosarcoma in clinical trials $(60,61)$ (Table 1). To date, there is one case report of possible association between lymphoma and terifluonomide (126). There are reports of possible other associations with breast and skin cancer in pharmacovigilance databases (127).

Both teriflunomide and leflunomide have been studied for their potent antitumor effects in different cancer types (62, 128) (Table 1). Interestingly, although DHODH is ubiquitously expressed, it is not overexpressed or mutated in malignant cells. However, its important role in cancer biology is thought to relate to malignant cells having a lower threshold for pyrimidine deprivation compared to non-malignant cells (129). Examples of anti-tumor mechanisms of teriflunomide and leflunomide include: down-regulation of anti-apoptotic proteins and growth factor receptors in cancer cells $(62,128)$, interruption of cancer cell survival signaling $(130,131)$, induction of cancer cell death (128, 132), abolishment of cancer stem cells (133), and cancer cell mitochondrial disruption (132). Teriflunomide may be an attractive anti-tumor medicine due to its efficacy at lower doses compared to other medications that inhibit DNA synthesis, such as methotrexate, and may thus avoid cumulative cytotoxic damage to the body (129). In particular, teriflunomide has been shown to improve basal cell carcinoma outcomes (134).

Leflunomide has been investigated in several clinical trials as an anti-cancer therapy, including metastatic triple negative cancers (NCT03709446), add-on therapy to mitoxantrone in stage IV prostate cancer (NCT00004071), add on to vemurafenib in metastatic melanoma (NCT01611675), as treatment for multiple melanoma (NCT02509052), anaplastic astrocytoma (NCT00003775), and glioblastoma multiforme (NCT00003293).

\section{Cladribine (Mavenclad)}

Cladribine is one of the newest DMTs approved for MS. As of 2019, cladribine has been approved in Europe and most recently approved in by the FDA in the US April 2019 for treatment of RRMS and SPMS.

Cladribine was synthesized in the 1980's as an adenosine analog, with resistance to adenosine deaminase due to a substitution of a chloride at the $2^{\prime}$-hydrogen position. In its phosphorylated form inside cells, cladribine is unable to diffuse out of the cell membrane and thus becomes trapped intracellularly (135). Cladribine's incorporation into the DNA chain, results in chain termination and ultimate cell death. Interestingly, cladribine is cytotoxic not only to dividing cells, but also to resting cells, suggesting alternative mechanism of action in non-dividing cells such as caspase- dependent (136) and caspase-independent (137) mechanisms, via direct mitochondrial toxicity $(137,138)$, inhibition of DNA repair (139) and epigenetic alterations (140).

Cladribine initially was thought to be specific to lymphocytes, given the observation of isolated lymphopenia in patients with severe combined immunodeficiency syndrome (SCID). Later discoveries of cladribine's toxicity to monocytes and macrophages raised the question of potential of cladribine to treat myeloid malignancies. Initial studies on cladribine have been done in pediatric acute myeloid leukemia (AML) (141143). Further studies in different cancers, including acute and chronic leukemias, mantle cell lymphoma, hairy cell leukemia, mucosa associated lymphoid tissue (MALT)-type lymphoma, and Langerhans cell histiocytosis have been done with combination therapies in both pediatric and adult populations (144-148). Cladribine's main adverse effects documented from the cancer studies, included significant immunosuppression associated with opportunistic infections such as herpes simplex, paresthesias, and possible secondary malignancy (149).

Cladribine was developed as a drug for MS given its lymphosuppressive actions, and in phase III trials in RRMS was shown to decrease disease activity in $45 \%$ of patients after 2 courses of treatment $(63,150)$. Due to a concern for inducing malignancy [a total of 10 cases in the active treatment arm of melanoma, ovarian carcinoma, pancreatic carcinoma, and myelodysplastic syndrome (63)] cladribine was rejected by FDA in 2010. However, a 2015 meta-analysis, comparing cancer risk in 11 phase III trials between different available DMTs at the time, including GA, natalizumab, dimethyl fumerate, tefiluonomide, and fingolimod, demonstrated that there was not a higher cancer risk in MS patients who were treated with cladribine, but rather that due to a placebo comparator, there was an exaggerated relative increased risk in the treatment groups (151). Other longterm studies in leukemia patients have also shown lack of an increase in secondary malignancies (147). Long-term monitoring for potential cancer side effects in MS patients on cladribine is warranted and has been recommended by EMA and FDA to determine the true cancer risk in this patient population.

\section{MONOCLONAL ANTIBODIES: ALEMTUZUMAB (LEMTRADA) AND B CELL THERAPIES: RITUXIMAB (RITUXAN, MAB THERA, RITEMVIA) AND OCRELIZUMAB (OCREVUS)}

\section{Alemtuzumab (Lemtrada)}

Alemtuzumab is a humanized monoclonal antibody directed against CD52, approved for MS in 2013. Treatment of alemtuzumab leads to significant depletion of $\mathrm{T}$ and $\mathrm{B}$ lymphocytes, natural killer (NK) cells, dendritic cells, 
granulocytes, and monocytes via several mechanisms (152). First, by activating $\mathrm{Clq}$ and generation of the membrane attack complex, alemtuzumab leads to complement-dependent cytotoxicity. Second, by activation of NK cells and macrophages through their IgG fragment $C$ receptor, alemtuzumab contributes to antibody-dependent cellular cytotoxicity. Lastly, alemtuzumab can also result in induction of apoptosis. The final result of alemtuzumab is profound depletion of peripheral lymphocytes that occurs within hours-days post infusion and is sustained for up to 1 year (153). B cells tend to repopulate faster than T cells, contributing to an immune imbalance, which may explain some of the autoimmune side effects associated with Lemtrada (154).

As CD52 is expressed on the cell surface of both normal and malignant lymphocytes, alemtuzumab has been an important therapy for several cancer types for over 20 years prior to its approval as an MS therapy. In fact, alemtuzumab, under the name camcath, was used in the 1980's for the treatment of Hodgkin's lymphoma, and was FDA approved in 2001 for the treatment of chronic lymphocytic leukemia (CLL) (67). Over the years, alemtuzumab has been used to treat lymphomas and leukemias, including $\mathrm{T}$ cell lymphomas, peripheral $\mathrm{T}$ cell lymphomanot otherwise specified (PTCL-NOS), T cell prolymphocytic leukemia (T-PLL), cutaneous T cell lymphoma (CTCL) and adult T cell lymphoma/leukemia (ATLL) as well as B cell malignancies, such as B-cell non-Hodgkin's lymphoma (B-NHL) and B-cell chronic lymphocytic lymphoma (B-CLL).

Several malignancies have been associated with alemtuzumab use in RRMS, including stage 1 thyroid papillary carcinoma with onset 10-41 months from the last infusion, basal cell carcinoma, breast cancer, melanoma, non-EBV-associated Burkitt' s lymphoma, and Castleman disease. Overall, out of 1,486 alemtuzumab treated-patients in 3 clinical trials, 29 patients developed malignancies, at variable times post treatment (Table 1).

\section{B Cell Therapies: Rituximab (Rituxan), Ocrelizumab (Ocrevus)}

Rituximab and ocrelizumab, anti-CD20 B cell depleting monoclonal antibodies, have become critical agents in the management of MS, underlying the importance of B cells in the pathophysiology of MS. Rituximab is a chimeric monoclonal antibody targeted against $\mathrm{CD} 20$, while ocrelizumab is a humanized anti-CD20 agent. Although not FDA approved in demyelinating diseases, rituximab is widely used in the treatment of MS and Neuromyelitis Optica. Ocrelizumab was FDA approved in 2017 for RRMS and primary progressive multiple sclerosis (PPMS) based on two large phase III trials (OPERA I and II) (71). Further anti-CD20 agents, currently in late stages of the development pipeline, include ofatumumab and ublituximab. The anti-CD20 therapies lead to elimination of CD20 expressing pre-B cells and mature lymphocytes via a variety of mechanisms, including antibody-dependent cellular cytotoxicity (ADCC), antibody-dependent cellular phagocytosis, complement-dependent cytotoxicity (CDC), cell death via apoptosis and decreased antibody production (155) (Figure 3).

$\mathrm{B}$ cells are well recognized for their role in modulating the immune response in cancer. Tumor metabolites, like leukotriene B4, can attract B cells to tumor sites and promote differentiation of $\mathrm{B}$ regs and $\mathrm{T}$ regs, and shifting the immune milieu from CD8 and T-helper 1 (Th1) to Th2-driven response (156). While a more regulatory immune environment is beneficial in autoimmune conditions such as MS, the shift to Breg/Tregs/Th2 prevents the host immune system from detecting and lysing tumor cells and could fuel cancer growth via IL35 and IL10 producing Bregs (Figure 3). In addition, another subset of B cells, CD5p B cells, can promote several cancer cell types (157). Also, the presence of CD19+ B cells may be associated with worse outcomes in metastatic ovarian carcinoma (158).

Importantly, the CD20 cell surface marker is found on most malignant B cells. Thus, anti-CD20 therapies, such as rituximab have earned a prominent role in treatment of cancers, including B cell lymphomas, Hodgkin lymphoma, Burkitt lymphoma, and B cell lymphoblastic leukemias (69). Second and third generation anti-CD20 monoclonal antibodies, ocrelizumab and ofatumumab, have shown promise as alternative cancer therapies in patients with intolerance to rituximab (159). However, in contrast to rituximab, there is no long-term safety data on these newer second and third generation agents.

Despite the success of anti-CD20 monoclonal antibodies in cancer treatment, there are also several cancers associated with the use of anti-B cell therapies. For example, ocrelizumab was associated with several cases of malignancy in clinical trials, including cases of renal cancer, melanoma, and breast cancers. Overall, 4 malignancies were reported in OPERA 1 trial in RRMS patients and 11 malignancies were reported in PPMS patients in the ORATORIO trial (70).

Reasons for cancer predisposition on B cell therapies may have to do with the potentially protective role of $\mathrm{B}$ cells in tumor microenivronments as APCs and activators of NK and cytolytic $\mathrm{T}$ cells targeted toward lysis of tumors. A recent cancer profiling study has linked a B cell gene signature to fast proliferating tumors, such as breast cancers, suggesting that suppression of a $\mathrm{B}$ cell response in breast cancer could contribute to less favorable outcomes (160). Other studies have also demonstrated that B cell presence, and specifically CD20 B cells, are linked to a better prognosis in breast cancer $(161,162)$. Similarly, it has been demonstrated that co-presence of both CD20 B cells and CD8 T cells in the tumor environment improves survival in ovarian cancer (163). Interestingly, the timing of anti-B cell therapy may also dictate type of tumor response. For example, one study found that treatment of mice with anti-CD20 therapy prior to tumor challenge resulted in elimination of cancer metastasis. In comparison, treatment with anti-CD20 therapy post tumor challenge, enhanced tumor cell survival and metastasis (164). Thus, timing of anti-B cell therapy in context of cancer comorbidities in MS may be an important factor in clinical decision making.

\section{ANTIOXIDANT PATHWAY Dimethyl Fumerate (Tecfidera)}

Initially used in the treatment of psoriasis, dimethyl fumerate (DMF) was approved for use in MS in 2013. Although the mechanism of action of DMF is not completely understood in MS, DMF is thought to be an immunomodulatory therapy that decreases inflammatory $\mathrm{T}$ cells via increasing nuclear factor 


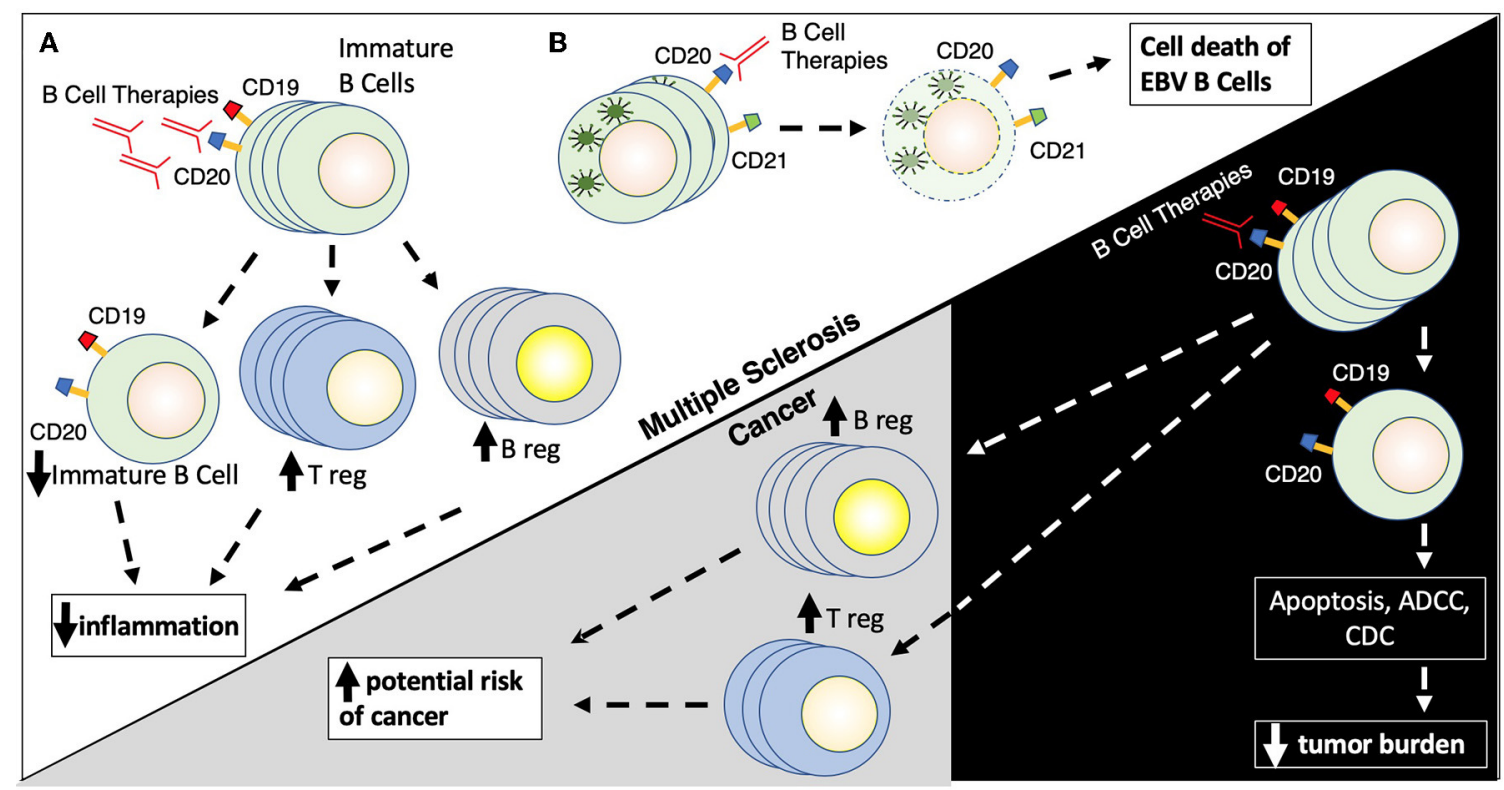

FIGURE 3 | (A,B) B cell therapies. B cell therapies play a role in the treatment of both multiple sclerosis and cancer, but yet can also promote cancer development. Rituximab targets CD20 found on the surface of immature (naïve) B cells (CD19/CD20+) leading to their destruction by several mechanisms including apoptosis, antibody-dependent cell cytotoxicity, and complement directed cytotoxicity. Rituximab also promotes the proliferation of $\mathrm{T}$ regulatory cells (Treg) and B regulator cells (Breg) which results in reduced inflammation. Rituximab has similar actions in the context of cancer, where elimination of CD19/CD20+ B cells leads to a reduction of tumor burden in patients with B cell malignancies, while elevations in Breg and Treg populations can promote possible tumor formation.

erythroid 2-related factor 2 (Nrf2) and glutathione (GSH), the cell's regulators of anti-oxidant response (Figure 4) (165). DMF is derived from fumaric acid and is metabolized into monomethyl fumerate (MMF), the active component responsible for DMF's anti-inflammatory and antioxidant effects. DMF was associated with a low level of malignancies in the DEFINE and CONFIRM clinical trials, accounting for $<1 \%$ of all adverse events (Table 1).

A number of preclinical studies have explored the benefits of DMF and MMF in anti-cancer activity via impact on the cell's apoptotic machinery. DMF has been shown to be cytotoxic in patient and mouse derived cancer cell lines from lung and colon adenocarcinoma with KRAS mutations, likely via effect on decreasing activity of the Nrf2/DJ-1 antioxidant pathway and contributing to cancer cell death $(75,76)$. Several studies have illustrated positive role of DMF in melanoma tumor suppression via mechanisms interfering with cancer cell proliferation or contributing to apoptosis and cell cycle inhibition. For example, DMF was shown to decrease melanoma metastasis as well as lymph node metastasis in a SCID mouse model $(166,167)$. In another study, DMF inhibited growth and metastasis of melanoma tumors by suppressing metalloproteases and inhibiting entry of nuclear factor $B$ and its transcription factor p65 into the nucleus (168). Study of DMF's role in cell cycle arrest, demonstrated that DMF inhibited melanoma cell line proliferation via interference with cell cycle proteins and upregulation of tumor suppressor, p53 (169). In a separate study, DMF induced cell death in colon carcinoma cells, via depletion of GSH and activation of mitogen-activated protein kinase (MAPK) (170). In a breast cancer cell line, it was found that via blockade of transcription factor p65 in the nuclear factor B (NFK B) pathway, DMF is able to retard tumor proliferation and xenograft tumor growth (171). Both DMF and MMF were found to retard tumor growth in primary human glioblastoma cell lines alone or in combination with other anti-tumor medications in the proteasome inhibitor family (e.g., velcade and carfilzomib) (77).

As a result of these pre-clinical studies, several clinical trials are currently underway to evaluate the role of DMF in cancer, including a trial in refractory leukemia/lymphoma, NCT02784834; glioblastoma, NCT02337426; and Cutaneous T Cell Lymphoma, NCT02546440.

\section{CONCLUSIONS AND FUTURE DIRECTIONS}

The salient role of the immune system is to defend the body from invasive pathogens and cancers, while preserving tolerance to self-antigens. Both cancer and autoimmune disorders, such as MS, result from immune dysregulation. In MS, the immune system reacts too strongly in self-protection, resulting in demyelination of the central nervous system. Cancer cells adapt to either evade standard immune checks and balances or directly influence an immune phenotype conducive toward malignant proliferation, such as via recruitment and differentiation of Tregs, B regs, CD5p B, and CD19+ B cells within the tumor microenvironment.

An important goal in successful management of MS patients is to resolve how to (i) best therapeutically manipulate the 


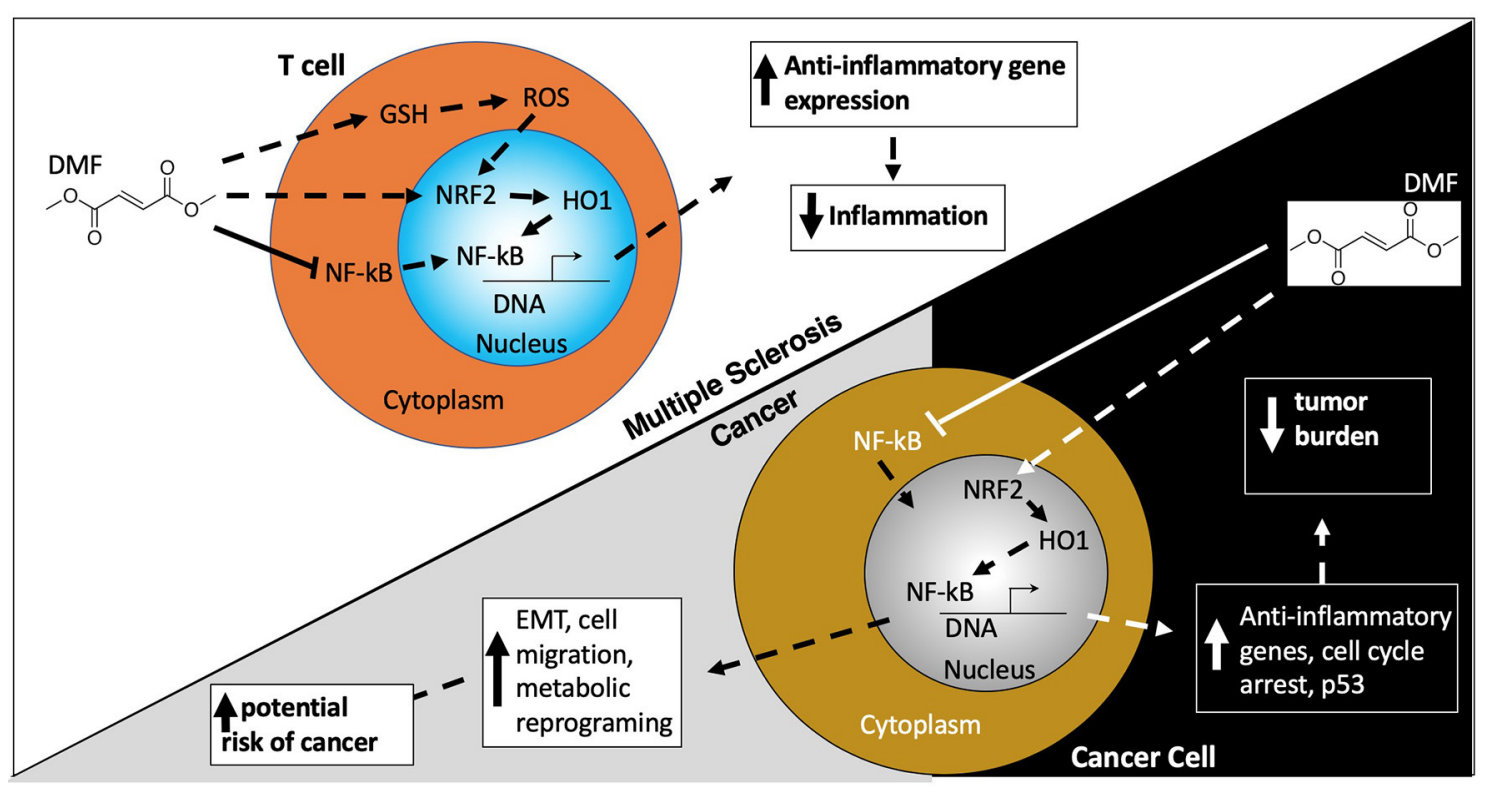

FIGURE 4 | Dimethyl fumerate. Dimethyl Fumerate (DMF) ultimately enhances the activity of the transcription factor nuclear factor (erythroid-derived 2)-like 2 (NRF2) leading to transcription of anti-inflammatory genes, serving as the basis for DMF's beneficial effects in MS patients. In cancer cells, these same actions together with alterations in cell cycle protein and p53 expression, serve to attenuate cancer growth and proliferation. However, paradoxically DMF can also promote epithelial to mesenchymal transition (EMT) which enhances migration and metastasis. DMF may also alter the metabolic environment in cancer cells which aids their survival, growth, and proliferation.

immune system without promoting cancer and how to (ii) treat MS patients who develop cancer while on a DMT. It is noteworthy that many of the current DMTs have potential anti-tumor mechanisms. Examples, such as basal cell carcinoma improvement with terifluonomide treatment (134) suggest that a DMT should not be stopped at cancer diagnosis, but rather each individual's case should be considered in context of their specific risk factors for cancer. Thus, in making treatment decisions for MS patients with cancer, it is imperative that clinicians consider the potential mechanism of action of available DMTs to determine how best to manage both the cancer risk and the risk of rebound MS.

In addition, it is also critical that clinicians think about patient-specific risks. Both pre-clinical and clinical studies demonstrate that not all individuals with MS develop cancer and cancer side effect of MS DMTs are tissue specific (Table 1). What may account for this patient heterogeneity is not wellunderstood, but likely has to do with context dependent cues, such as an individual's cultural background and genetics, being male vs. female, diet, composition of the gut microbiome, length of treatment on DMTs, and likely other not yet recognized factors.

Toward the idea of personalized risk assessment, it is likely important that sex differences should be considered in treatment of MS and cancer. An important example is recent data on immune checkpoint inhibitors, demonstrating that there is a significant difference in immune responses in men and women, with the higher possibility for males to benefit from cancer immunotherapies (172). Some MS studies have also hinted at sex-specific responses to DMTs, potentially due to sexually dimorphic immune responses $(173,174)$. While more studies are necessary to determine exact cancer risks that male and female MS patients may experience on specific DMTs, it is prudent that sex differences in response to DMTs should be considered at initiation or discontinuation of DMTs when a patient develops cancer.

Another potential factor that may differentially determine a person's predisposition for and treatment of MS (175-177) and cancer (178-180) is the gut microbiome. The human gut microbiome consists of bacteria, fungi, archaea, protozoa, and viruses that have evolved symbiotic relationship with the human host (181). Trillions of gut microbiota mediate multiple functions for the host, and in particular help shape the immune system (182-184). In MS, studies have shown that transfer of fecal microbiota transplant (FMT) from patients with MS to recipient mice can induce experimental autoimmune encephalomyelitis (EAE), MS-like disease in mice (185-187), suggesting that gut microbes are a vital aspect of autoimmune induction. Likewise, cancer phenotypes can be transferred via FMT (188). Gut bacteria can also help to fight autoimmunity and cancer by modulating host immunity (189) and improving outcomes of immunotherapy treatments (190). Interestingly, butyrate producing bacteria have been shown to be beneficial in both MS $(191,192)$ and cancer $(193,194)$, via effects on cellular proliferation and apoptosis as well as immune effects on the blood brain barrier and remyelination. Given the importance of the gut microbiome in both autoimmunity and cancer, it is exciting to view the manipulation of the gut microbial 
populations as an avenue for future management of MS and cancer. There are still many questions about how gut bacteria can influence the course of immunity at organs distant from the gut, and whether same bacteria may influence immunity differentially in autoimmune conditions vs. cancer. For example, Bifidobacteria, Akkermansia, and Bacteroides are increased in patients with MS, but may lead to anti-tumor outcomes in cancer patients $(195,196)$. Research to better delineate which bacterial species are most conducive to promoting favorable vs. unfavorable immune outcomes in MS and cancer, will help to pave the road toward more precise risk assessment and manipulation of the gut microbiome in patients with MS and cancer.

In summary, given the wide array of currently available DMTs with potential to promote and treat cancer, it is important for clinicians to be aware of the risks and benefits of prescribing these agents to MS patients, particularly to patients with a history of cancer. Future efforts should be directed toward developing a clearer understanding of the relative risk and incidence of cancer in patients taking specific DMTs. One possible solution would be creation of a curated data base and establishment of uniform standards and guidelines on reporting and management of patients with MS and a history of cancer who are candidates for DMTs. In addition, there is a need for development of clinical recommendations for frequency and type of monitoring for malignancy screening on individual DMTs as well as research and

\section{REFERENCES}

1. Bahmanyar S, Montgomery SM, Hillert J, Ekbom A, Olsson T. Cancer risk among patients with multiple sclerosis and their parents. Neurology. (2009) 72:1170-7. doi: 10.1212/01.wnl.0000345366.10455.62

2. Midgard R, Glattre E, Grønning M, Riise T, Edland A, Nyland H. Multiple sclerosis and cancer in Norway A retrospective cohort study. Acta Neurol Scand. (1996) 93:411-5. doi: 10.1111/j.1600-0404.1996.tb00019.x

3. Nielsen NM, Rostgaard K, Rasmussen S, Koch-Henriksen N, Storm HH, Melbye $\mathrm{M}$, et al. Cancer risk among patients with multiple sclerosis: a population-based register study. Int J Cancer. (2006) 118:979-84. doi: $10.1002 /$ ijc. 21437

4. Thormann A, Koch-Henriksen N, Laursen B, Sorensen PS, Magyari M. Inverse comorbidity in multiple sclerosis: findings in a complete nationwide cohort. Mult Scler Relat Disord. (2016) 10:181-6. doi: 10.1016/j.msard.2016.10.008

5. Lebrun C, Debouverie M, Vermersch P, Clavelou P, Rumbach L, De Seze J, et al. Cancer risk and impact of disease-modifying treatments in patients with multiple sclerosis. Mult Scler J. (2008) 14:399-405. doi: $10.1177 / 1352458507083625$

6. Palo J, Duchesne J, Wikström J. Malignant diseases among patients with multiple sclerosis. J Neurol. (1977) 216:217-22. doi: 10.1007/BF00313623

7. Etemadifar M, Jahanbani-Ardakani H, Ghaffari S, Fereidan-Esfahani M, Changaei H, Aghadoost N, et al. Cancer risk among patients with multiple sclerosis: a cohort study in Isfahan, Iran. Caspian J Intern Med. (2017) 8:1727. doi: $10.22088 /$ cjim.8.3.172

8. Møller H, Kneller R, Boice JD Jr, Olsen JH. Cancer incidence following hospitalization for multiple sclerosis in Denmark. Acta Neurol Scand. (1991) 84:214-20. doi: 10.1111/j.1600-0404.1991.tb04941.x

9. Achiron A, Barak Y, Gail M, Mandel M, Pee D, Ayyagari R, et al. Cancer incidence in multiple sclerosis and effects of immunomodulatory treatments. Breast Cancer Res Treat. (2005) 89:265-70. doi: 10.1007/s10549-0042229-4 recommendations for how to transition MS patients to alternate DMTs if cancer arises. Further research on sex differences and the role of the environmental factors, such as the gut microbiome in MS and cancer, will allow for an integrated pathway toward treating both conditions in a personalized way.

\section{AUTHOR CONTRIBUTIONS}

EM and ML: take responsibility for the integrity of the data and the accuracy of the data analysis, acquisition and interpretation, and the critical revision of the manuscript for important intellectual content. EM: concept and design and drafting of the manuscript.

\section{FUNDING}

This work was funded by Dell Medical School start-up funds to EM. The funder had no role in the design and conduct of the study; collection, management, analysis, and interpretation of the data; preparation, review, or approval of the manuscript; and decision to submit the manuscript for publication.

\section{ACKNOWLEDGMENTS}

We thank Ashlea Lucas, PA-C for the helpful discussions and Dr. William Schwartz for the critical reading of the manuscript.

10. Sumelahti ML, Pukkala E, Hakama M. Cancer incidence in multiple sclerosis: a 35-year follow-up. Neuroepidemiology. (2004) 23:224-7. doi: 10.1159/000079947

11. Kingwell E, Bajdik C, Phillips N, Zhu F, Oger J, Hashimoto S, et al. Cancer risk in multiple sclerosis: findings from British Columbia, Canada. Brain J Neurol. (2012) 135:2973-9. doi: 10.1093/brain/aws148

12. Catalá-López F, Suárez-Pinilla M, Suárez-Pinilla P, Valderas JM, GómezBeneyto M, Martinez S, et al. Inverse and direct cancer comorbidity in people with central nervous system disorders: a meta-analysis of cancer incidence in 577,013 participants of 50 observational studies. Psychother Psychosom. (2014) 83:89-105. doi: 10.1159/000356498

13. Fois AF, Wotton CJ, Yeates D, Turner MR, Goldacre MJ. Cancer in patients with motor neuron disease, multiple sclerosis and Parkinson's disease: record linkage studies. J Neurol Neurosurg Psychiatry. (2010) 81:215-21. doi: 10.1136/jnnp.2009.175463

14. Gaindh D, Kavak KS, Teter B, Vaughn CB, Cookfair D, Hahn T, et al. Decreased risk of cancer in multiple sclerosis patients and analysis of the effect of disease modifying therapies on cancer risk. J Neurol Sci. (2016) 370:13-7. doi: 10.1016/j.jns.2016.09.005

15. Hajiebrahimi M, Montgomery S, Burkill S, Bahmanyar S. Risk of premenopausal and postmenopausal breast cancer among multiple sclerosis patients. PLoS ONE. (2016) 11:e0165027. doi: 10.1371/journal.pone.0165027

16. Lebrun C, Vermersch P, Brassat D, Defer G, Rumbach L, Clavelou P, et al. Cancer and multiple sclerosis in the era of disease-modifying treatments. $J$ Neurol. (2011) 258:1304-11. doi: 10.1007/s00415-011-5929-9

17. Ragonese P, Aridon P, Vazzoler G, Mazzola MA, Lo Re V, Lo Re $\mathrm{M}$, et al. Association between multiple sclerosis, cancer risk, and immunosuppressant treatment: a cohort study. BMC Neurol. (2017) 17:155. doi: 10.1186/s12883-017-0932-0

18. Moisset X, Perie M, Pereira B, Dumont E, Lebrun-Frenay C, Lesage FX, et al. Decreased prevalence of cancer in patients with multiple sclerosis: a case-control study. PLoS ONE. (2017) 12:e0188120. doi: 10.1371/journal.pone.0188120 
19. Norgaard M, Veres K, Didden EM, Wormser D, Magyari M. Multiple sclerosis and cancer incidence: a Danish nationwide cohort study. Mult Scler Relat Disord. (2019) 28:81-5. doi: 10.1016/j.msard.2018.12.014

20. Bekisz J, Sato Y, Johnson C, Husain SR, Puri RK, Zoon KC. Immunomodulatory effects of interferons in malignancies. $J$ Interferon Cytokine Res. (2013) 33:154-61. doi: 10.1089/jir.20 12.0167

21. Magyari M, Søndergaard HB, Sellebjerg F, Sørensen PS. Preserved in vivo response to interferon-alpha in multiple sclerosis patients with neutralising antibodies against interferon-beta (REPAIR study). Mult Scler Relat Disord. (2013) 2:141-6. doi: 10.1016/j.msard.2012.10.001

22. Myhr K, Riise T, Lilleås FG, Beiske T, Celius E, Edland A, et al. Interferon$\alpha 2$ a reduces MRI disease activity in relapsing-remitting multiple sclerosis. Neurology. (1999) 52:1049. doi: 10.1212/WNL.52.5.1049

23. Hojati Z, Kay M, Dehghanian F. Mechanism of action of interferon beta in treatment of multiple sclerosis. In: Multiple Sclerosis. Academic Press (2016). p. 365-92. doi: 10.1016/B978-0-12-800763-1.00015-4

24. Parker BS, Rautela J, Hertzog PJ. Antitumour actions of interferons: implications for cancer therapy. Nat Rev Cancer. (2016) 16:131-44. doi: 10.1038/nrc.2016.14

25. Vitale G, de Herder WW, van Koetsveld PM, Waaijers M, Schoordijk W, Croze E, et al. IFN-beta is a highly potent inhibitor of gastroenteropancreatic neuroendocrine tumor cell growth in vitro. Cancer Res. (2006) 66:554-62. doi: 10.1158/0008-5472.CAN-05-3043

26. Vitale G, van Eijck CH, van Koetsveld Ing PM, Erdmann JI, Speel EJ, van der Wansem Ing K, et al. Type I interferons in the treatment of pancreatic cancer: mechanisms of action and role of related receptors. Ann Surg. (2007) 246:259-68. doi: 10.1097/01.sla.0000261460.07110.f2

27. Ivashkiv LB, Donlin LT. Regulation of type I interferon responses. Nat Rev Immunol. (2014) 14:36-49. doi: 10.1038/nri3581

28. Jakimovski D, Kolb C, Ramanathan M, Zivadinov R, Weinstock-Guttman B. Interferon $\beta$ for multiple sclerosis. Cold Spring Harbor Perspect Med. (2018) 8:a032003. doi: $10.1101 /$ cshperspect.a032003

29. Dhib-Jalbut $S$, Marks S. Interferon- $\beta$ mechanisms of action in multiple sclerosis. Neurology. (2010) 74:S17-24. doi: 10.1212/WNL.0b013e3181c97d99

30. Mattei F, Schiavoni G, Belardelli F, Tough DF. IL-15 is expressed by dendritic cells in response to type I IFN, double-stranded RNA, or lipopolysaccharide and promotes dendritic cell activation. The J Immunol. (2001) 167:1179-87. doi: 10.4049/jimmunol.167.3.1179

31. Schiavoni G, Mattei F, Gabriele L. Type I interferons as stimulators of DCmediated cross-priming: impact on anti-tumor response. Front Immunol. (2013) 4:483. doi: 10.3389/fimmu.2013.00483

32. Fuertes MB, Kacha AK, Kline J, Woo S-R, Kranz DM, Murphy KM, et al. Host type I IFN signals are required for antitumor CD8 $+\mathrm{T}$ cell responses through CD8 $\alpha+$ dendritic cells. J Exp Med. (2011) 208:2005-16. doi: 10.1084/jem.20101159

33. Pace L, Vitale S, Dettori B, Palombi C, La Sorsa V, Belardelli F, et al. APC activation by IFN- $\alpha$ decreases regulatory $\mathrm{T}$ cell and enhances Th cell functions. J Immunol. (2010) 184:5969-79. doi: 10.4049/jimmunol.0900526

34. de Paus RA, van Wengen A, Schmidt I, Visser M, Verdegaal EM, van Dissel JT, et al. Inhibition of the type I immune responses of human monocytes by IFN-alpha and IFN-beta. Cytokine. (2013) 61:645-55. doi: 10.1016/j.cyto.2012.12.005

35. Dedoni S, Olianas MC, Onali P. Interferon- $\beta$ induces apoptosis in human SH-SY5Y neuroblastoma cells through activation of JAK-STAT signaling and down-regulation of PI3K/Akt pathway. J Neurochem. (2010) 115:142133. doi: 10.1111/j.1471-4159.2010.07046.x

36. Chawla-Sarkar M, Leaman DW, Borden EC. Preferential induction of apoptosis by interferon (IFN)- $\beta$ compared with IFN- $\alpha 2$ : correlation with TRAIL/Apo2L induction in melanoma cell lines. Clin Cancer Res. (2001) 7:1821-31.

37. Apelbaum A, Yarden G, Warszawski S, Harari D, Schreiber G. Type I interferons induce apoptosis by balancing cFLIP and caspase8 independent of death ligands. Mol Cell Biol. (2013) 33:800-14. doi: 10.1128/MCB.01430-12

38. Ye Z, Dong H, Li Y, Ma T, Huang H, Leong HS, et al. Prevalent homozygous deletions of type I interferon and defensin genes in human cancers associate with immunotherapy resistance. Clin Cancer Res. (2018) 24:3299-308 doi: 10.1158/1078-0432.CCR-17-3008

39. Kingwell E, Evans C, Zhu F, Oger J, Hashimoto S, Tremlett H. Assessment of cancer risk with beta-interferon treatment for multiple sclerosis. J Neurol Neurosurg Psychiatry. (2014) 85:1096-102. doi: 10.1136/jnnp-2013-307238

40. Arnon R. The development of Cop 1 (Copaxone $(\mathrm{R})$ ), and innovative drug for the treatment of multiple sclerosis: personal reflections. Immunol Lett. (1996) 50:1-15. doi: 10.1016/0165-2478(96)02506-0

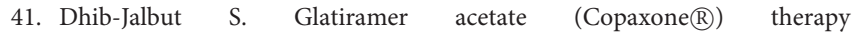
for multiple sclerosis. Pharmacol Therap. (2003) 98:245-55. doi: 10.1016/S0163-7258(03)00036-6

42. Prod'homme T, Zamvil SS. The evolving mechanisms of action of glatiramer acetate. Cold Spring Harb Perspect Med. (2019) 9:a029249. doi: 10.1101/cshperspect.a029249

43. Carter NJ, Keating GM. Glatiramer acetate. Drugs. (2010) 70:1545-77. doi: 10.2165/11204560-000000000-00000

44. Madray MM, Greene JF, Butler DF. Glatiramer acetate-associated, CD30+, primary, cutaneous, anaplastic large-cell lymphoma. Arch Neurol. (2008) 65:1378-9. doi: 10.1001/archneur.65.10.1378

45. Walker J, Smylie A, Smylie M. An association between glatiramer acetate and malignant melanoma. J Immunother. (2016) 39:276-8. doi: 10.1097/CJI.0000000000000131

46. Steinman L. Blocking adhesion molecules as therapy for multiple sclerosis: natalizumab. Nat Rev Drug Discov. (2005) 4:510-8. doi: 10.1038/nrd1752

47. Huang R, Rofstad EK. Integrins as therapeutic targets in the organ-specific metastasis of human malignant melanoma. J Exp Clin Cancer Res. (2018) 37:92. doi: 10.1186/s13046-018-0763-x

48. Mori Y, Shimizu N, Dallas M, Niewolna M, Story B, Williams PJ, et al. Anti- $\alpha 4$ integrin antibody suppresses the development of multiple myeloma and associated osteoclastic osteolysis. Blood. (2004) 104:2149-54. doi: 10.1182/blood-2004-01-0236

49. Garofalo A, Chirivi RG, Foglieni C, Pigott R, Mortarini R, MartinPadura I, et al. Involvement of the very late antigen 4 integrin on melanoma in interleukin 1-augmented experimental metastases. Cancer Res. (1995) 55:414-9.

50. Wolf K, Mazo I, Leung H, Engelke K, Von Andrian UH, Deryugina EI, et al. Compensation mechanism in tumor cell migration: mesenchymalamoeboid transition after blocking of pericellular proteolysis. J Cell Biol. (2003) 160:267-77. doi: 10.1083/jcb.200209006

51. Reder AT, Feng X. How type I interferons work in multiple sclerosis and other diseases: some unexpected mechanisms. I Interferon Cytokine Res. (2014) 34:589-99. doi: 10.1089/jir.2013.0158

52. Polman $\mathrm{CH}$, O'connor PW, Havrdova E, Hutchinson M, Kappos L, Miller DH, et al. A randomized, placebo-controlled trial of natalizumab for relapsing multiple sclerosis. N Engl J Med. (2006) 354:899-910. doi: 10.1056/NEJMoa044397

53. Calabresi PA, Radue E-W, Goodin D, Jeffery D, Rammohan KW, Reder AT, et al. Safety and efficacy of fingolimod in patients with relapsing-remitting multiple sclerosis (FREEDOMS II): a double-blind, randomised, placebo-controlled, phase 3 trial. Lancet Neurol. (2014) 13:54556. doi: 10.1016/S1474-4422(14)70049-3

54. Cohen JA, Barkhof F, Comi G, Hartung HP, Khatri BO, Montalban X, et al. Oral fingolimod or intramuscular interferon for relapsing multiple sclerosis. N Engl J Med. (2010) 362:402-15. doi: 10.1056/NEJMoa0907839

55. Comi G, O’Connor P, Montalban X, Antel J, Radue E, Karlsson G, et al. Phase II study of oral fingolimod (FTY720) in multiple sclerosis: 3-year results. Mult Scler J. (2010) 16:197-207. doi: 10.1177/1352458509357065

56. Lublin F, Miller DH, Freedman MS, Cree BA, Wolinsky JS, Weiner H, et al. Oral fingolimod in primary progressive multiple sclerosis (INFORMS): a phase 3, randomised, double-blind, placebo-controlled trial. Lancet. (2016) 387:1075-84. doi: 10.1016/S0140-6736(15)01314-8

57. Cuvillier O. Downregulating sphingosine kinase-1 for cancer therapy. Expert Opin Therap Targets. (2008) 12:1009-20. doi: 10.1517/14728222.12.8.1009

58. White C, Alshaker H, Cooper C, Winkler M, Pchejetski D. The emerging role of FTY720 (Fingolimod) in cancer treatment. Oncotarget. (2016) 7:23106. doi: 10.18632/oncotarget.7145

59. Kappos L, Bar-Or A, Cree BA, Fox RJ, Giovannoni G, Gold R, et al. Siponimod versus placebo in secondary progressive multiple 
sclerosis (EXPAND): a double-blind, randomised, phase 3 study. Lancet. (2018) 391:1263-73. doi: 10.1016/S0140-6736(18)30475-6

60. O'Connor P, Wolinsky JS, Confavreux C, Comi G, Kappos L, Olsson TP, et al. Randomized trial of oral teriflunomide for relapsing multiple sclerosis. $N$ Engl J Med. (2011) 365:1293-303. doi: 10.1056/NEJMoa1014656

61. Vermersch P, Czlonkowska A, Grimaldi LM, Confavreux C, Comi G, Kappos $\mathrm{L}$, et al. Teriflunomide versus subcutaneous interferon beta- $1 \mathrm{a}$ in patients with relapsing multiple sclerosis: a randomised, controlled phase 3 trial. Mult Scler J. (2014) 20:705-16. doi: 10.1177/1352458513507821

62. Huang O, Zhang W, Zhi Q, Xue X, Liu H, Shen D, et al. Teriflunomide, an immunomodulatory drug, exerts anticancer activity in triple negative breast cancer cells. Exp Biol Med. (2015) 240:426-37. doi: $10.1177 / 1535370214554881$

63. Giovannoni G, Comi G, Cook S, Rammohan K, Rieckmann P, Sørensen PS, et al. A placebo-controlled trial of oral cladribine for relapsing multiple sclerosis. N Engl J Med. (2010) 362:416-26. doi: 10.1056/NEJMoa0902533

64. Lee MW, Parker WB, Xu B. New insights into the synergism of nucleoside analogs with radiotherapy. Radiation Oncol. (2013) 8:223. doi: 10.1186/1748-717X-8-223

65. Coles AJ, Cohen JA, Fox EJ, Giovannoni G, Hartung H-P, Havrdova E, et al. Alemtuzumab CARE-MS II 5-year follow-up: efficacy and safety findings. Neurology. (2017) 89:1117-26. doi: 10.1212/WNL.0000000000004354

66. Havrdova E, Arnold DL, Cohen JA, Hartung H-P, Fox EJ, Giovannoni G, et al. Alemtuzumab CARE-MS I 5-year follow-up: durable efficacy in the absence of continuous MS therapy. Neurology. (2017) 89:1107-16. doi: 10.1212/WNL.0000000000004313

67. Demko S, Summers J, Keegan P, Pazdur R. FDA drug approval summary: alemtuzumab as single-agent treatment for B-cell chronic lymphocytic leukemia. Oncologist. (2008) 13:167-74. doi: 10.1634/theoncologist.2007-0218

68. Salzer J, Svenningsson R, Alping P, Novakova L, Björck A, Fink K, et al. Rituximab in multiple sclerosis: a retrospective observational study on safety and efficacy. Neurology. (2016) 87:2074-81. doi: 10.1212/WNL.0000000000003331

69. Salles G, Barrett M, Foà R, Maurer J, O’Brien S, Valente N, et al. Rituximab in B-cell hematologic malignancies: a review of 20 years of clinical experience. Adv Ther. (2017) 34:2232-73. doi: 10.1007/s12325-017-0612-x

70. Montalban X, Hauser SL, Kappos L, Arnold DL, Bar-Or A, Comi G, et al. Ocrelizumab versus placebo in primary progressive multiple sclerosis. $\mathrm{N}$ Engl J Med. (2017) 376:209-20. doi: 10.1056/NEJMoa1606468

71. Hauser SL, Bar-Or A, Comi G, Giovannoni G, Hartung HP, Hemmer B, et al. Ocrelizumab versus Interferon Beta-1a in Relapsing Multiple Sclerosis. $N$ Engl J Med. (2017) 376:221-34. doi: 10.1056/NEJMoa1601277

72. Morschhauser F, Marlton P, Vitolo U, Lindén O, Seymour J, Crump M, et al. Results of a phase I/II study of ocrelizumab, a fully humanized anti-CD20 $\mathrm{mAb}$, in patients with relapsed/refractory follicular lymphoma. Ann Oncol. (2010) 21:1870-6. doi: 10.1093/annonc/mdq027

73. Gold R, Kappos L, Arnold DL, Bar-Or A, Giovannoni G, Selmaj K, et al. Placebo-controlled phase 3 study of oral BG-12 for relapsing multiple sclerosis. N Engl J Med. (2012) 367:1098-107. doi: 10.1056/NEJMoa1114287

74. Fox RJ, Miller DH, Phillips JT, Hutchinson M, Havrdova E, Kita M, et al. Placebo-controlled phase 3 study of oral BG-12 or glatiramer in multiple sclerosis. N Engl J Med. (2012) 367:1087-97. doi: 10.1056/NEJMoa1206328

75. Bennett Saidu NE, Bretagne M, Mansuet AL, Just PA, Leroy K, Cerles $\mathrm{O}$, et al. Dimethyl fumarate is highly cytotoxic in KRAS mutated cancer cells but spares non-tumorigenic cells. Oncotarget. (2018) 9:9088-99. doi: $10.18632 /$ oncotarget. 24144

76. Saidu NE, Noe G, Cerles O, Cabel L, Kavian-Tessler N, Chouzenoux $\mathrm{S}$, et al. Dimethyl fumarate controls the NRF2/DJ-1 axis in cancer cells: therapeutic applications. Mol Cancer Ther. (2017) 16:529-39. doi: 10.1158/1535-7163.MCT-16-0405

77. Booth L, Cruickshanks N, Tavallai S, Roberts JL, Peery M, Poklepovic A, et al. Regulation of dimethyl-fumarate toxicity by proteasome inhibitors. Cancer Biol Ther. (2014) 15:1646-57. doi: 10.4161/15384047.2014.967992

78. Sabol RA, Noxon V, Sartor O, Berger JR, Qureshi Z, Raisch DW, et al. Melanoma complicating treatment with natalizumab for multiple sclerosis: a report from the Southern Network on Adverse Reactions (SONAR). Cancer Med. (2017) 6:1541-51. doi: 10.1002/cam4.1098
79. Qian F, Vaux DL, Weissman IL. Expression of the integrin $\alpha 4 \beta 1$ on melanoma cells can inhibit the invasive stage of metastasis formation. Cell. (1994) 77:335-47. doi: 10.1016/0092-8674(94)90149-X

80. Adachi K, Kohara T, Nakao N, Arita M, Chiba K, Mishina T, et al. Design, synthesis, and structure-activity relationships of 2-substituted-2-amino-1, 3propanediols: discovery of a novel immunosuppressant, FTY720. Bioorgan Med Chem Lett. (1995) 5:853-6. doi: 10.1016/0960-894X(95)00127-F

81. Chiba K, Yanagawa Y, Masubuchi Y, Kataoka H, Kawaguchi T, Ohtsuki $\mathrm{M}$, et al. FTY720, a novel immunosuppressant, induces sequestration of circulating mature lymphocytes by acceleration of lymphocyte homing in rats. I. FTY720 selectively decreases the number of circulating mature lymphocytes by acceleration of lymphocyte homing. I Immunol. (1998) 160:5037-44. doi: 10.1046/j.1365-2567.1998.00639.x

82. Fujita T, Hirose R, Yoneta M, Sasaki S, Inoue K, Kiuchi M, et al. Potent immunosuppressants, 2-alkyl-2-aminopropane-1, 3-diols. J Med Chem. (1996) 39:4451-9. doi: 10.1021/jm9603911

83. Huwiler A, Zangemeister-Wittke U. The sphingosine 1-phosphate receptor modulator fingolimod as a therapeutic agent: recent findings and new perspectives. Pharmacol Therap. (2018) 185:34-49. doi: 10.1016/j.pharmthera.2017.11.001

84. Mandala S, Hajdu R, Bergstrom J, Quackenbush E, Xie J, Milligan J, et al. Alteration of lymphocyte trafficking by sphingosine-1-phosphate receptor agonists. Science. (2002) 296:346-9. doi: 10.1126/science.1070238

85. Jackson SJ, Giovannoni G, Baker D. Fingolimod modulates microglial activation to augment markers of remyelination. J Neuroinflamm. (2011) 8:76. doi: $10.1186 / 1742-2094-8-76$

86. Beckham TH, Cheng JC, Marrison ST, Norris JS, Liu X. Interdiction of sphingolipid metabolism to improve standard cancer therapies. Adv Cancer Res. (2013) 117:1-36. doi: 10.1016/B978-0-12-394274-6.00001-7

87. Azuma H, Takahara S, Horie S, Muto S, Otsuki Y, Katsuoka Y. Induction of apoptosis in human bladder cancer cells in vitro and in vivo caused by FTY720 treatment. J Urol. (2003) 169:2372-7. doi: 10.1097/01.ju.0000064938.32318.91

88. Azuma $\mathrm{H}$, Takahara S, Ichimaru N, Wang JD, Itoh $\mathrm{Y}$, Otsuki $\mathrm{Y}$, et al. Marked prevention of tumor growth and metastasis by a novel immunosuppressive agent, FTY720, in mouse breast cancer models. Cancer Res. (2002) 62:1410-9.

89. Lim KG, Tonelli F, Li Z, Lu X, Bittman R, Pyne S, et al. FTY720 analogues as sphingosine kinase 1 inhibitors: enzyme inhibition kinetics, allosterism, proteasomal degradation, and actin rearrangement in MCF-7 breast cancer cells. J Biol Chem. (2011) 286:18633-40. doi: 10.1074/jbc.M111. 220756

90. Nagaoka Y, Otsuki K, Fujita T, Uesato S. Effects of phosphorylation of immunomodulatory agent FTY720 (fingolimod) on antiproliferative activity against breast and colon cancer cells. Biol Pharm Bull. (2008) 31:1177-81. doi: 10.1248/bpb.31.1177

91. Tonelli F, Lim KG, Loveridge C, Long J, Pitson SM, Tigyi G, et al. FTY720 and (S)-FTY720 vinylphosphonate inhibit sphingosine kinase 1 and promote its proteasomal degradation in human pulmonary artery smooth muscle, breast cancer and androgen-independent prostate cancer cells. Cell Signal. (2010) 22:1536-42. doi: 10.1016/j.cellsig.2010.05.022

92. Estrada-Bernal A, Palanichamy K, Ray Chaudhury A, Van Brocklyn JR. Induction of brain tumor stem cell apoptosis by FTY720: a potential therapeutic agent for glioblastoma. Neuro Oncol. (2012) 14:405-15. doi: 10.1093/neuonc/nos005

93. Zhang L, Wang H, Zhu J, Ding K, Xu J. FTY720 reduces migration and invasion of human glioblastoma cell lines via inhibiting the PI3K/AKT/mTOR/p70S6K signaling pathway. Tumor Biol. (2014) 35:1070714. doi: $10.1007 / \mathrm{s} 13277-014-2386-y$

94. Hung J-H, Lu Y-S, Wang Y-C, Ma Y-H, Wang D-S, Kulp SK, et al. FTY720 induces apoptosis in hepatocellular carcinoma cells through activation of protein kinase C $\delta$ signaling. Cancer Res. (2008) 68:1204-12. doi: 10.1158/0008-5472.CAN-07-2621

95. Lee TK, Man K, Ho JW, Wang XH, Poon RT, Xu Y, et al. FTY720: a promising agent for treatment of metastatic hepatocellular carcinoma. Clin Cancer Res. (2005) 11:8458-66. doi: 10.1158/1078-0432.CCR-05-0447

96. Omar HA, Chou CC, Berman-Booty LD, Ma Y, Hung JH, Wang D, et al. Antitumor effects of OSU-2S, a nonimmunosuppressive analogue 
of FTY720, in hepatocellular carcinoma. Hepatology. (2011) 53:1943-58. doi: 10.1002/hep. 24293

97. Szymiczek A, Pastorino S, Larson D, Tanji M, Pellegrini L, Xue J, et al. FTY720 inhibits mesothelioma growth in vitro and in a syngeneic mouse model. J Transl Med. (2017) 15:58. doi: 10.1186/s12967-017-1158-z

98. Nagahara Y, Ikekita M, Shinomiya T. Immunosuppressant FTY720 induces apoptosis by direct induction of permeability transition and release of cytochrome c from mitochondria. J Immunol. (2000) 165:3250-9. doi: 10.4049/jimmunol.165.6.3250

99. Liu Q, Alinari L, Chen CS, Yan F, Dalton JT, Lapalombella R, et al. FTY720 shows promising in vitro and in vivo preclinical activity by downmodulating Cyclin D1 and phospho-Akt in mantle cell lymphoma. Clin Cancer Res. (2010) 16:3182-92. doi: 10.1158/1078-0432.CCR-09-2484

100. Neviani P, Santhanam R, Oaks JJ, Eiring AM, Notari M, Blaser BW, et al. FTY720, a new alternative for treating blast crisis chronic myelogenous leukemia and Philadelphia chromosome-positive acute lymphocytic leukemia. J Clin Invest. (2007) 117:2408-21. doi: 10.1172/JCI31095

101. Roberts KG, Smith AM, McDougall F, Carpenter H, Horan M, Neviani P, et al. Essential requirement for PP2A inhibition by the oncogenic receptor $\mathrm{c}$ KIT suggests PP2A reactivation as a strategy to treat c-KIT+ cancers. Cancer Res. (2010) 70:5438-47. doi: 10.1158/0008-5472.CAN-09-2544

102. Li D, Zhang Y, Hu X, Cao W, Huang W. Role of extracelluar regulated protein kinases in FTY720-induced apoptosis of leukemia cell lines HL60 and U937. J Huazhong Univ Sci Technol Med Sci. (2004) 24:45-7. doi: 10.1007/BF02830703

103. Liu Q, Zhao X, Frissora F, Ma Y, Santhanam R, Jarjoura D, et al. FTY720 demonstrates promising preclinical activity for chronic lymphocytic leukemia and lymphoblastic leukemia/lymphoma. Blood. (2008) 111:275-84. doi: 10.1182/blood-2006-10-053884

104. Fujino M, Li XK, Kitazawa Y, Guo L, Kawasaki M, Funeshima N, et al. Distinct pathways of apoptosis triggered by FTY720, etoposide, and antiFas antibody in human T-lymphoma cell line (Jurkat cells). J Pharmacol Exp Therap. (2002) 300:939-45. doi: 10.1124/jpet.300.3.939

105. Lucas da Silva LB, Ribeiro DA, Cury PM, Cordeiro JA, Bueno V. FTY720 treatment in experimentally urethane-induced lung tumors. J Exp Ther Oncol. (2008) 7:9-15.

106. Salinas NR, Lopes CT, Palma PV, Oshima CT, Bueno V. Lung tumor development in the presence of sphingosine 1-phosphate agonist FTY720. Pathol Oncol Res POR. (2009) 15:549-54. doi: 10.1007/s12253-009-9152-2

107. Salinas NR, Oshima CT, Cury PM, Cordeiro JA, Bueno V. FTY720 and lung tumor development. Int Immunopharmacol. (2009) 9:689-93. doi: 10.1016/j.intimp.2008.12.007

108. Ho JW, Man K, Sun CK, Lee TK, Poon RT, Fan ST. Effects of a novel immunomodulating agent, FTY720, on tumor growth and angiogenesis in hepatocellular carcinoma. Mol Cancer Ther. (2005) 4:1430-8. doi: 10.1158/1535-7163.MCT-05-0021

109. Shen Y, Wang X, Xia W, Wang C, Cai M, Xie H, et al. Antiproliferative and overadditive effects of rapamycin and FTY720 in pancreatic cancer cells in vitro. Transplant Proc. (2008) 40:1727-33. doi: 10.1016/j.transproceed.2008.03.150

110. Ubai T, Azuma H, Kotake Y, Inamoto T, Takahara K, Ito Y, et al. FTY720 induced Bcl-associated and Fas-independent apoptosis in human renal cancer cells in vitro and significantly reduced in vivo tumor growth in mouse xenograft. Anticancer Res. (2007) 27:75-88.

111. Sonoda Y, Yamamoto D, Sakurai S, Hasegawa M, Aizu-Yokota E, Momoi T, et al. FTY720, a novel immunosuppressive agent, induces apoptosis in human glioma cells. Biochem Biophys Res Commun. (2001) 281:282-8. doi: 10.1006/bbrc.2001.4352

112. Zheng T, Meng X, Wang J, Chen X, Yin D, Liang Y, et al. PTEN- and p53mediated apoptosis and cell cycle arrest by FTY720 in gastric cancer cells and nude mice. J Cell Biochem. (2010) 111:218-28. doi: 10.1002/jcb.22691

113. Zhang N, Qi Y, Wadham C, Wang L, Warren A, Di W, et al. FTY720 induces necrotic cell death and autophagy in ovarian cancer cells: a protective role of autophagy. Autophagy. (2010) 6:1157-67. doi: 10.4161/auto.6.8.13614

114. Cristobal I, Manso R, Rincon R, Carames C, Senin C, Borrero A, et al. PP2A inhibition is a common event in colorectal cancer and its restoration using FTY720 shows promising therapeutic potential. Mol Cancer Ther. (2014) 13:938-47. doi: 10.1158/1535-7163.MCT-13-0150
115. Rosa R, Marciano R, Malapelle U, Formisano L, Nappi L, D’Amato C, et al. Sphingosine kinase 1 overexpression contributes to cetuximab resistance in human colorectal cancer models. Clin Cancer Res. (2013) 19:138-47. doi: 10.1158/1078-0432.CCR-12-1050

116. LaMontagne K, Littlewood-Evans A, Schnell C, O’Reilly T, Wyder L, Sanchez $\mathrm{T}$, et al. Antagonism of sphingosine-1-phosphate receptors by FTY720 inhibits angiogenesis and tumor vascularization. Cancer Res. (2006) 66:22131. doi: 10.1158/0008-5472.CAN-05-2001

117. Chua CW, Lee DT, Ling MT, Zhou C, Man K, Ho J, et al. FTY720, a fungus metabolite, inhibits in vivo growth of androgen-independent prostate cancer. Int J Cancer. (2005) 117:1039-48. doi: 10.1002/ijc.21243

118. Wolf AM, Eller K, Zeiser R, Durr C, Gerlach UV, Sixt M, et al. The sphingosine 1-phosphate receptor agonist FTY720 potently inhibits regulatory $\mathrm{T}$ cell proliferation in vitro and in vivo. J Immunol. (2009) 183:3751-60. doi: 10.4049/jimmunol.0901011

119. Nishikawa $\mathrm{H}$, Sakaguchi S. Regulatory $\mathrm{T}$ cells in tumor immunity. Int $\mathrm{J}$ Cancer. (2010) 127:759-67. doi: 10.1002/ijc.25429

120. Domhan S, Zeier $M$, Abdollahi A. Immunosuppressive therapy and post-transplant malignancy. Nephrol Dial Transplant. (2009) 24:1097-103. doi: $10.1093 / \mathrm{ndt} / \mathrm{gfn} 605$

121. French KJ, Schrecengost RS, Lee BD, Zhuang Y, Smith SN, Eberly JL, et al. Discovery and evaluation of inhibitors of human sphingosine kinase. Cancer Res. (2003) 63:5962-9.

122. Zhang L, Wang H-D, Ji X-J, Cong Z-X, Zhu J-H, Zhou Y. FTY720 for cancer therapy. Oncol Rep. (2013) 30:2571-8. doi: 10.3892/or.2013.2765

123. Selmi C. Autoimmunity in 2016. Clin Rev Allergy Immunol. (2017) 53:12639. doi: 10.1007/s12016-017-8615-6

124. Rosaria CM. Addressing the potential role of fingolimod in cancer therapy. Med Chem. (2016) 6:3. doi: 10.4172/2161-0444.1000345

125. Hengst JA, Dick TE, Sharma A, Doi K, Hegde S, Tan S-F, et al. SKI-178: a multitargeted inhibitor of sphingosine kinase and microtubule dynamics demonstrating therapeutic efficacy in acute myeloid leukemia models. Cancer Transl Med. (2017) 3:109. doi: 10.4103/ctm.ctm_7_17

126. Landais A, Alhendi R, Gouverneur A, Teron-Aboud B. A case of lymphoma in a patient on teriflunomide treatment for relapsing multiple sclerosis. Mult Scler Relat Disord. (2017) 17:92-4. doi: 10.1016/j.msard.2017.07.001

127. Lebrun C, Rocher F. Cancer risk in patients with multiple sclerosis: potential impact of disease-modifying drugs. CNS Drugs. (2018) 32:939-49. doi: 10.1007/s40263-018-0564-y

128. Dietrich S, Krämer $\mathrm{OH}$, Hahn E, Schäfer C, Giese T, Hess $M$, et al. Leflunomide induces apoptosis in fludarabine-resistant and clinically refractory CLL cells. Clin Cancer Res. (2012) 18:417-31. doi: 10.1158/1078-0432.CCR-11-1049

129. Sykes DB. The emergence of dihydroorotate dehydrogenase (DHODH) as a therapeutic target in acute myeloid leukemia. Expert Opin Ther Targets. (2018) 22:893-8. doi: 10.1080/14728222.2018.1536748

130. Cook MR, Pinchot SN, Jaskula-Sztul R, Luo J, Kunnimalaiyaan M, Chen H. Identification of a novel Raf-1 pathway activator that inhibits gastrointestinal carcinoid cell growth. Mol Cancer Therap. (2010) 9:429-37. MCT-09-0718. doi: 10.1158/1535-7163.MCT-09-0718

131. Baumann P, Mandl-Weber S, Völkl A, Adam C, Bumeder I, Oduncu F, et al. Dihydroorotate dehydrogenase inhibitor A771726 (leflunomide) induces apoptosis and diminishes proliferation of multiple myeloma cells. Mol Cancer Therap. (2009) 8:366-75. doi: 10.1158/1535-7163.MCT-0 8-0664

132. Hail N Jr, Chen P, Bushman LR. Teriflunomide (leflunomide) promotes cytostatic, antioxidant, and apoptotic effects in transformed prostate epithelial cells: evidence supporting a role for teriflunomide in prostate cancer chemoprevention. Neoplasia. (2010) 12:464-75. doi: $10.1593 /$ neo. 10168

133. White RM, Cech J, Ratanasirintrawoot S, Lin CY, Rahl PB, Burke CJ, et al. DHODH modulates transcriptional elongation in the neural crest and melanoma. Nature. (2011) 471:518. doi: 10.1038/nature09882

134. DeWitt JP, Thomas KL, Sturgeon A. Regression of basal cell carcinomas in multiple sclerosis patient on Aubagio treatment. Southwest Respir Crit Care Chronicles. (2017) 5:55-6. doi: 10.12746/swrccc.v5i21.414

135. Hermann R, Karlsson MO, Novakovic AM, Terranova N, Fluck M, Munafo A. The clinical pharmacology of cladribine tablets for the treatment 
of relapsing multiple sclerosis. Clin Pharmacokinet. (2019) 58:283-97. doi: 10.1007/s40262-018-0695-9

136. Pastor-Anglada M, Molina-Arcas M, Casado F, Bellosillo B, Colomer D, Gil J. Nucleoside transporters in chronic lymphocytic leukaemia. Leukemia. (2004) 18:385. doi: $10.1038 /$ sj.leu.2403271

137. Marzo I, Pérez-Galán P, Giraldo P, Rubio-Félix D, Alberto A, Naval J. Cladribine induces apoptosis in human leukaemia cells by caspasedependent and-independent pathways acting on mitochondria. Biochem J. (2001) 359:537-46. doi: 10.1042/bj3590537

138. Genini D, Adachi S, Chao Q, Rose DW, Carrera CJ, Cottam HB, et al. Deoxyadenosine analogs induce programmed cell death in chronic lymphocytic leukemia cells by damaging the DNA and by directly affecting the mitochondria. Blood. (2000) 96:3537-43. doi: 10.1182/blood.V96.10.3537

139. Pettitt AR, Sherrington PD, Cawley JC. Role of poly (ADP-ribosyl) ation in the killing of chronic lymphocytic leukemia cells by purine analogues. Cancer Res. (2000) 60:4187-93.

140. Warzocha K, Fabianowska-Majewska K, Blonski J, Krykowski E, Robak T. 2-Chlorodeoxyadenosine inhibits activity of adenosine deaminase and S-adenosylhomocysteine hydrolase in patients with chronic lymphocytic leukaemia. Eur J Cancer. (1997) 33:170-3. doi: 10.1016/S0959-8049(96)00347-4

141. Inaba H, Stewart CF, Crews KR, Yang S, Pounds S, Pui CH, et al. Combination of cladribine plus topotecan for recurrent or refractory pediatric acute myeloid leukemia. Cancer Interdiscipl Int J Am Cancer Soc. (2010) 116:98-105. doi: 10.1002/cncr.24712

142. Santana VM, Mirro J Jr, Kearns C, Schell MJ, Crom W, Blakley RL. 2-Chlorodeoxyadenosine produces a high rate of complete hematologic remission in relapsed acute myeloid leukemia. J Clin Oncol. (1992) 10:36470. doi: 10.1200/JCO.1992.10.3.364

143. Santana V, Mirro J Jr, Harwood F, Cherrie J, Schell M, Kalwinsky D, et al. A phase I clinical trial of 2-chlorodeoxyadenosine in pediatric patients with acute leukemia. J Clin Oncol. (1991) 9:416-22. doi: 10.1200/JCO.1991.9. 3.416

144. Freyer CW, Gupta N, Wetzler M, Wang ES. Revisiting the role of cladribine in acute myeloid leukemia: an improvement on past accomplishments or more old news? Am J Hematol. (2015) 90:62-72. doi: 10.1002/ajh.23862

145. Stine KC, Saylors RL, Saccente S, McClain KL, Becton DL. Efficacy of continuous infusion 2-CDA (cladribine) in pediatric patients with Langerhans cell histiocytosis. Pediatric Blood Cancer. (2004) 43:81-4. doi: 10.1002/pbc.20053

146. Jäger G, Neumeister P, Brezinschek R, Hinterleitner T, Fiebiger W, Penz M, et al. Treatment of extranodal marginal zone B-cell lymphoma of mucosaassociated lymphoid tissue type with cladribine: a phase II study. J Clin Oncol. (2002) 20:3872-7. doi: 10.1200/JCO.2002.05.117

147. Rosenberg JD, Burian C, Waalen J, Saven A. Clinical characteristics and long-term outcome of young hairy cell leukemia patients treated with cladribine: a single-institution series. Blood. (2014) 123:177-83. doi: 10.1182/blood-2013-06-508754

148. Inwards DJ, Fishkin P, LaPlant B, Drake M, Kurtin P, Nikcevich D, et al. Phase I trial of rituximab, cladribine, and temsirolimus (RCT) for initial therapy of mantle cell lymphoma. Ann Oncol. (2014) 25:2020-4. doi: 10.1093/annonc/mdu273

149. Dasanu CA, Alexandrescu DT. Risk of additional cancers in untreated and treated hairy cell leukemia patients. Expert Opin Pharmacother. (2010) 11:41-50. doi: 10.1517/14656560903405647

150. Giovannoni G, Cook S, Rammohan K, Rieckmann P, Sørensen PS, Vermersch P, et al. Sustained disease-activity-free status in patients with relapsing-remitting multiple sclerosis treated with cladribine tablets in the CLARITY study: a post-hoc and subgroup analysis. Lancet Neurol. (2011) 10:329-37. doi: 10.1016/S1474-4422(11)70023-0

151. Pakpoor J, Disanto G, Altmann DR, Pavitt S, Turner BP, Marta M, et al. No evidence for higher risk of cancer in patients with multiple sclerosis taking cladribine. Neurol Neuroimmunol Neuroinflamm. (2015) 2:e158. doi: 10.1212/NXI.0000000000000158

152. Cox AL, Thompson SA, Jones JL, Robertson VH, Hale G, Waldmann $\mathrm{H}$, et al. Lymphocyte homeostasis following therapeutic lymphocyte depletion in multiple sclerosis. Eur J Immunol. (2005) 35:3332-42. doi: 10.1002/eji.200535075
153. Tridente G. Alemtuzumab. In: Adverse Events With Biomedicines. Italy: Giuseppe Tridente University of Verona Verona. (2014). p. 81-95.

154. Baker D, Herrod SS, Alvarez-Gonzalez C, Giovannoni G, Schmierer $\mathrm{K}$. Interpreting lymphocyte reconstitution data from the pivotal phase 3 trials of alemtuzumab. JAMA Neurol. (2017) 74:961-9. doi: 10.1001/jamaneurol.2017.0676

155. Cornet E, Tomowiak C, Tanguy-Schmidt A, Lepretre S, Dupuis J, Feugier P, et al. Long-term follow-up and second malignancies in 487 patients with hairy cell leukaemia. Br J Haematol. (2014) 166:390-400. doi: 10.1111/bjh.12908

156. Schwartz M, Zhang Y, Rosenblatt JD. B cell regulation of the anti-tumor response and role in carcinogenesis. J Immunother Cancer. (2016) 4:40. doi: 10.1186/s40425-016-0145-x

157. Sarvaria A, Madrigal JA, Saudemont A. B cell regulation in cancer and anti-tumor immunity. Cell Mol Immunol. (2017) 14:662-74. doi: $10.1038 / \mathrm{cmi} .2017 .35$

158. Dong HP, Elstrand MB, Holth A, Silins I, Berner A, Trope CG, et al. NK-and B-cell infiltration correlates with worse outcome in metastatic ovarian carcinoma. Am J Clin Pathol. (2006) 125:451-8. doi: 10.1309/15B6-6DQM-FYYM-78CJ

159. Chen LY, Shah R, Cwynarski K, Lambert J, McNamara C, Mohamedbhai $\mathrm{SG}$, et al. Ofatumumab is a feasible alternative anti-CD20 therapy in patients intolerant of rituximab. Br J Haematol. (2019) 184:462. doi: 10.1111/bjh.15110

160. Schmidt M, Böhm D, Von Törne C, Steiner E, Puhl A, Pilch H, et al. The humoral immune system has a key prognostic impact in node-negative breast cancer. Cancer Res. (2008) 68:5405-13. doi: 10.1158/0008-5472.CAN-07-5206

161. Arias-Pulido H, Cimino-Mathews A, Chaher N, Qualls C, Joste N, Colpaert $\mathrm{C}$, et al. The combined presence of CD20 + B cells and PD-L1 + tumorinfiltrating lymphocytes in inflammatory breast cancer is prognostic of improved patient outcome. Breast Cancer Res Treat. (2018) 171:273-82. doi: 10.1007/s10549-018-4834-7

162. Brown JR, Wimberly H, Lannin DR, Nixon C, Rimm DL, Bossuyt V. Multiplexed quantitative analysis of $\mathrm{CD} 3, \mathrm{CD} 8$, and $\mathrm{CD} 20$ predicts response to neoadjuvant chemotherapy in breast cancer. Clin Cancer Res. (2014) 20:5995-6005. doi: 10.1158/1078-0432.CCR-14-1622

163. Nielsen JS, Sahota RA, Milne K, Kost SE, Nesslinger NJ, Watson $\mathrm{PH}$, et al. $\mathrm{CD} 20+$ tumor-infiltrating lymphocytes have an atypical CD27- memory phenotype and together with CD8+ T cells promote favorable prognosis in ovarian cancer. Clin Cancer Res. (2012) 18:3281-92. doi: 10.1158/1078-0432.CCR-12-0234

164. Bodogai M, Chang CL, Wejksza K, Lai J, Merino M, Wersto RP, et al. AntiCD20 antibody promotes cancer escape via enrichment of tumor-evoked regulatory B cells expressing low levels of CD20 and CD137L. Cancer Res. (2013) 73:2127-38. doi: 10.1158/0008-5472.CAN-12-4184

165. Mills EA, Ogrodnik MA, Plave A, Mao-Draayer Y. Emerging understanding of the mechanism of action for dimethyl fumarate in the treatment of multiple sclerosis. Front Neurol. (2018) 9:5. doi: 10.3389/fneur.2018.00005

166. Loewe R, Valero T, Kremling S, Pratscher B, Kunstfeld R, Pehamberger H, et al. Dimethylfumarate impairs melanoma growth and metastasis. Cancer Res. (2006) 66:11888-96. doi: 10.1158/0008-5472.CAN-06-2397

167. Valero T, Steele S, Neumuller K, Bracher A, Niederleithner H, Pehamberger $\mathrm{H}$, et al. Combination of dacarbazine and dimethylfumarate efficiently reduces melanoma lymph node metastasis. J Invest Dermatol. (2010) 130:1087-94. doi: 10.1038/jid.2009.368

168. Yamazoe Y, Tsubaki M, Matsuoka H, Satou T, Itoh T, Kusunoki $\mathrm{T}$, et al. Dimethylfumarate inhibits tumor cell invasion and metastasis by suppressing the expression and activities of matrix metalloproteinases in melanoma cells. Cell Biol Int. (2009) 33:1087-94. doi: 10.1016/j.cellbi.2009.06.027

169. Kaluzki I, Hrgovic I, Hailemariam-Jahn T, Doll M, Kleemann J, Valesky EM, et al. Dimethylfumarate inhibits melanoma cell proliferation via p21 and p53 induction and bcl-2 and cyclin B1 downregulation. Tumour Biol. (2016) 37:13627-35. doi: 10.1007/s13277-016-5285-6

170. Xie X, Zhao Y, Ma CY, Xu XM, Zhang YQ, Wang CG, et al. Dimethyl fumarate induces necroptosis in colon cancer cells through GSH depletion/ROS increase/MAPKs activation pathway. Br J Pharmacol. (2015) 172:3929-43. doi: 10.1111/bph.13184 
171. Kastrati I, Siklos MI, Calderon-Gierszal EL, El-Shennawy L, Georgieva G, Thayer EN, et al. Dimethyl fumarate inhibits the nuclear factor kappab pathway in breast cancer cells by covalent modification of p65 protein. J Biol Chem. (2016) 291:3639-47. doi: 10.1074/jbc.M115.679704

172. Conforti F, Pala L, Bagnardi V, De Pas T, Martinetti M, Viale $\mathrm{G}$, et al. Cancer immunotherapy efficacy and patients' sex: a systematic review and meta-analysis. Lancet Oncol. (2018) 19:737-46. doi: 10.1016/S1470-2045(18)30261-4

173. Li DKB, Zhao GJ, Paty DW. Randomized controlled trial of interferon-beta1a in secondary progressive MS. MRI results. Neurology. (2001) 56:1505-13. doi: 10.1212/WNL.56.11.1505

174. Contasta I, Totaro R, Pellegrini P, Del Beato T, Carolei A, Berghella AM. A gender-related action of IFNbeta-therapy was found in multiple sclerosis. $J$ Transl Med. (2012) 10:223. doi: 10.1186/1479-5876-10-223

175. van den Hoogen WJ, Laman JD, t Hart BA. Modulation of multiple sclerosis and its animal model experimental autoimmune encephalomyelitis by food and gut microbiota. Front Immunol. (2017) 8:1081. doi: 10.3389/fimmu.2017.01081

176. Cantarel BL, Waubant E, Chehoud C, Kuczynski J, DeSantis TZ, Warrington J, et al. Gut microbiota in multiple sclerosis: possible influence of immunomodulators. J Invest Med. (2015) 63:729-34. doi: 10.1097/JIM.0000000000000192

177. Mangalam AK. Drugs, bugs, and MS: the interplay between diseasemodifying therapy and gut microbiota. Neurol Neuroimmunol Neuroinflamm. (2019) 6:e524. doi: 10.1212/NXI.0000000000000524

178. Elinav E, Garrett WS, Trinchieri G, Wargo J. The cancer microbiome. Nat Rev Cancer. (2019) 19:371-6. doi: 10.1038/s41568-019-0155-3

179. Routy B, Le Chatelier E, Derosa L, Duong CP, Alou MT, Daillère R, et al. Gut microbiome influences efficacy of PD-1-based immunotherapy against epithelial tumors. Science. (2018) 359:91-7.

180. Gopalakrishnan V, Spencer C, Nezi L, Reuben A, Andrews M, Karpinets T, et al. Gut microbiome modulates response to anti-PD1 immunotherapy in melanoma patients. Science. (2018) 359:97-103. doi: 10.1126/science.aan4236

181. Tremlett H, Bauer KC, Appel-Cresswell S, Finlay BB, Waubant E. The gut microbiome in human neurological disease: a review. Ann Neurol. (2017) 81:369-82. doi: 10.1002/ana.24901

182. Vaziri ND, Zhao Y-Y, Pahl MV. Altered intestinal microbial flora and impaired epithelial barrier structure and function in CKD: the nature, mechanisms, consequences and potential treatment. Nephrol Dialysis Transpl. (2015) 31:737-46. doi: 10.1093/ndt/gfv095

183. Harrison OJ, Powrie FM. Regulatory $\mathrm{T}$ cells and immune tolerance in the intestine. Cold Spring Harbor Perspect Biol. (2013) 5:a018341. doi: 10.1101/cshperspect.a018341

184. Schirmer M, Smeekens SP, Vlamakis H, Jaeger M, Oosting M, Franzosa EA, et al. Linking the human gut microbiome to inflammatory cytokine production capacity. Cell. (2016) 167:1125-36. e8. doi: 10.1016/j.cell.2016.10.020

185. Berer K, Gerdes LA, Cekanaviciute E, Jia X, Xiao L, Xia Z, et al. Gut microbiota from multiple sclerosis patients enables spontaneous autoimmune encephalomyelitis in mice. Proc Natl Acad Sci USA. (2017) 114:10719-24. doi: 10.1073/pnas.1711233114
186. Cekanaviciute E, Yoo BB, Runia TF, Debelius JW, Singh S, Nelson CA, et al. Gut bacteria from multiple sclerosis patients modulate human $\mathrm{T}$ cells and exacerbate symptoms in mouse models. Proc Natl Acad Sci USA. (2017) 114:10713-8. doi: 10.1073/pnas.1716911114

187. Berer K, Mues M, Koutrolos M, Al Rasbi Z, Boziki M, Johner C, et al. Commensal microbiota and myelin autoantigen cooperate to trigger autoimmune demyelination. Nature. (2011) 479:538. doi: 10.1038/nature10554

188. Poutahidis T, Cappelle K, Levkovich T, Lee CW, Doulberis M, Ge Z, et al. Pathogenic intestinal bacteria enhance prostate cancer development via systemic activation of immune cells in mice. PLoS ONE. (2013) 8:e73933. doi: 10.1371/journal.pone.0073933

189. Zitvogel L, Daillere R, Roberti MP, Routy B, Kroemer G. Anticancer effects of the microbiome and its products. Nat Rev Microbiol. (2017) 15:465. doi: 10.1038/nrmicro.2017.44

190. Vétizou M, Pitt JM, Daillère R, Lepage P, Waldschmitt N, Flament C, et al. Anticancer immunotherapy by CTLA-4 blockade relies on the gut microbiota. Science. (2015) 350:1079-84. doi: 10.1126/science.aad1329

191. Chen T, Noto D, Hoshino Y, Mizuno M, Miyake S. Butyrate suppresses demyelination and enhances remyelination. J Neuroinflamm. (2019) 16:165. doi: 10.1186/s12974-019-1552-y

192. Melbye P, Olsson A, Hansen TH, Søndergaard HB, Bang Oturai A. Shortchain fatty acids and gut microbiota in multiple sclerosis. Acta Neurol Scand. (2019) 139:208-19. doi: 10.1111/ane.13045

193. Sengupta S, Muir JG, Gibson PR. Does butyrate protect from colorectal cancer? J Gastroenterol Hepatol. (2006) 21(1 Pt 2):209-18. doi: 10.1111/j.1440-1746.2006.04213.x

194. Encarnação JC, Pires AS, Amaral RA, Gonçalves TJ, Laranjo M, CasaltaLopes JE, et al. Butyrate, a dietary fiber derivative that improves irinotecan effect in colon cancer cells. J Nutr Biochem. (2018) 56:183-92. doi: 10.1016/j.jnutbio.2018.02.018

195. Li W, Deng Y, Chu Q, Zhang P. Gut microbiome and cancer immunotherapy. Cancer Lett. (2019) 447:41-7. doi: 10.1016/j.canlet.2019.01.015

196. Budhram A, Parvathy S, Kremenchutzky M, Silverman M. Breaking down the gut microbiome composition in multiple sclerosis. Mult Scler. (2017) 23:628-36. doi: 10.1177/1352458516 682105

Conflict of Interest: EM has served as a consultant for EMD Serono and Genentech.

The remaining author declares that the research was conducted in the absence of any commercial or financial relationships that could be construed as a potential conflict of interest.

Copyright (c) 2020 Melamed and Lee. This is an open-access article distributed under the terms of the Creative Commons Attribution License (CC BY). The use, distribution or reproduction in other forums is permitted, provided the original author(s) and the copyright owner(s) are credited and that the original publication in this journal is cited, in accordance with accepted academic practice. No use, distribution or reproduction is permitted which does not comply with these terms. 